\title{
V.M. GOLDSCHMIDT CONFERENCE 1994
}

This volume contains the extended abstracts of papers presented from 29th August to 2nd September, 1994, at the Conference organised by the European Association of Geochemistry and the University of Edinburgh.

\section{Principal Supporting Institutions of Conference}

Geochemical Society

European Association of Geochemistry

International Association for Geochemistry and Cosmochemistry

Mineralogical Society of Great Britain and Ireland

\section{Editorial and Programme Committee}

B. Harte (principal editor)

A.H. Bath

P. Beattie

M.J. Bickle

A.C.M. Bourg

J.M. Brenan

R.A. Cliff

D.R. Cole

M.L. Coleman

C.D. Curtis

J.I. Drever

H. Elderfield

R.M. Ellam

A.E. Fallick

T.J. Falloon

C.M. Graham

D.H. Green

A.N. Halliday

S.L. Harley

C.J. Hawkesworth
B.J. Hensen

A.W. Hofmann

P.J. Hooker

S.E. Humphris

S. Inger

M. Kastner

M.D. Krom

A.C. Lasaga

R.K. O’Nions

A. Payne

T.F. Pedersen

F.M. Phillips

R.M.F. Preston

G.D. Price

R. Raiswell

G.B. Shimmield

E.M. Stolper

J. Veizer

J.R. Wijbrans

B.J. Wood 


\section{MINERALOGICAL MAGAZINE}

VOLUME 58A

AUGUST 1994

\section{M. GOLDSCHMIDT CONFERENCE, EDINBURGH 1994}

\section{EXTENDED ABSTRACTS}

Abstracts arranged in alphabetical order of first authors

\section{CONTENTS}

Author Index

Subject Index

Abstracts A-K (first part)

Abstracts L-Z (second part) 
Abart, R.

Abbott, M.J.

Abercrombie, H.J.

Abouchami, W.

Adair, B.I.

Agapova, A.A.

Aggarwal, J.K.

Akagi, T.

Al'mukhamedov, A.I.

Albarède, $F$.

Albrecht, A.

Alexandre, G.A.L.

Allègre, C.J.

Alt, J.C.

Altabet, M.A.

Amrhein, C.

Andersson, E.

Andersson, P.S.

Ando, $T$.

Andre, $\mathrm{L}$.

Andresdottir, A.

Andronikov, A.V.

Aparicio, A.

Appelo, C.A.J.

Aquilina, L.

Araña, V.

Arculus, R.J.

Ármannsson, $\mathrm{H}$.

Arnaudá, N.O.

Arnórsson, $\mathrm{S}$.

Arslan, M.

Ash, R.D.

Ashton, J.H.

Atkins, $M$.

Austin, W.E.N.

Ayora, C.

Ayres, $\mathrm{M}$.

Azaroual, M.

Bachelery, P.

Bacon, M.P.

Bailey, A.M.

Bailey, D.K.

Bailey, E.H.

Baker, D.R.

Baker, J.

Baker, M.B.

Baldridge, W.S.

Ballhaus, C.

Banks, D.A.

Baram, P.S.

Barbey, P.

Barclay, J.

Barling, J.
Barnes, H.L.

Barnes, S.-J.

Barnicoat, A.

Barnicoat, A.C.

579 Barreiro, B.A.

107

5

7

617

9

11,13

887

14, 627,

874

88

15,288

523

17

442

947

259

752

19

21

23

25,225

21

473

333

468

27, 333

493

331

109

29

31

32

34,380

36, 286

Barry, $\mathrm{T}$.

Bartlett, J.M.

Barton, E.S.

Basalaeva, I.V.

Basile, I.

Bassett, W.A.

Batanova, V.G.

Bateman, K.

Bath, A.H.

Batiza, R.

Bau, M.

Baumgartner, L.P.

Beattie, P.

Bebié, J.

Becker, $\mathrm{H}$.

Beer, J.

Bégin, N.J.

Bell, $\mathrm{K}$.

Belshaw, N.S.

Ben Baccar, M.

Ben Othman, D.

Bénézeth, $P$.

Benner, E.

Benning, L.G.

Bernasconi, S.

Berndt, M.E.

Berner, R.A.

Berry, J.A.

Bertram, C.

Beveridge, $N$.

Bevins, R.E.

Beynon, J.

Bezmen, N.I.

Bickle, M.J.

Biehler, D.

Biino, G.G.

288

38

776

926

40, 207,

434,559

42

44

844

46

994

688

877

48

49
Billo, S.M.

Bindeman, I.N.

Birke, M.

Bishop, H.E.

Bizzi, L.A.

Black, P.

Black, $S$.

Blackson, J.H.

Blake, S.

Blencoe, J.G.

Blichert-Toft, J.

Bloch, J.

Blum, A.E.

Blum, J.D.

Blundy, J.D.
299
51,835
758
53
95
21
5

364, 456

233

565

823

57

59, 779

603

335

61, 329

924

63

65

67

11,13

694

69

1004

549

77,541

71

73

75

295, 561

79

183

81

83

83

601

85

87

85, 88,

90

261

92, 591

94

969

95

81

581

432

916

38

783

97

99

150

967

255

101
Bock, B.

103

Boggs, K.J.E. $\quad 105$

Borodaev, Yu.S.

Bortnikov, N.S.

Bottazzi, P.

633

107

756,912 ,

932,998

Boulegue, J.

Bourdon, B.

Bourgeois, R.

Bowen, D.Q.

Boyce, A.J.

Boyd, F.R.

Boyd, W.W.

Boyle, E.

Boyle, E.A.

Brake, C.R.

Brandon, A.D.

Brantley, S.L.

Braun, I.

Brenan, J.M.

Brewer, T.S.

Bricker, O.P.

Brodholt, J.P.

Brooker, R.A.

Brown, G.

Brown, $\mathrm{M}$.

Brown, W.L.

Bruckschen, P.

Bruhn, F.

Buatier, $\mathrm{M}$.

Buhl, D.

Buick, I.S.

Burch, T.E.

Burdige, D.J.

Burgess, R.

Burley, S.D.

Burnett, D.S.

Burton, K.W.

Bustillo, M.

Bustillo, M.A.

Caboi, R.

173

Calcara, $M$.

750

Calvert, S.E. $\quad 313$

Cama, J.

140

Cameron, E.M. $\quad 142$

Cameron, R.L. $\quad 754$

Capobianco, C.J. 144

Cardenal, J.

Carmichael, I.

146,955

Carrington, D.P.

858

152

Carroll, M.R.

Cartwright, I.

48,470

53,130 ,

154

Casey, W.H.

Castet, S. 
Catlow, C.R.A.

Cave, $M$.

Cawood, P.A.

Cerling, T.E.

Chacko, T.

Chalimourda, A.

Chapman, H.J.

Charnock, J.M.

Chaussidon, $\mathrm{M}$.

Chauvel, C.

Chazot, G.

Chenery, S.

Chernyshov, I.V.

Chilcott, $\mathrm{C}$.

Chou, I-M.

Chou, L.

Christensen, J.N.

Christie, D.M.

Chubarov, V.N.

Chudaeva, V.A.

Chung, J.

Churikova, T.G.

Chávez-García, M.L.

Cidu, $\mathbf{R}$.

Class, C.

Clayton, R.N.

Clayton, $\mathrm{T}$.

Clemens, S.C.

Cliff, B.

Clocchiatti, R.

Clow, D.W.

Cocherie, A.

Cochran, M.F.

Cohen, A.S.

Cole, C.

Cole, D.R.

Coleman, M.L.

Cooper, G.I.

Corriveau, L.

Cosca, M.A.

Costa, S.

Cowper, M.M.

Cox, G.A.

Cramp, A.

Crawford, A.J.

Crawford, M.B.

Creaser, R.A.

Crocket, J.H.

Croudace, I.W.

Crozaz, G.

Crum, J.

Cundy, A.B.
247,990
158
977
160
115,161
265
730
85,90
819
163,356

368,877

165

167,573

732

107

914

823

728

366

651

669,670

169

156

171

682

173

175

177

898

179

758

807

239

181

183

185

187

132, 189

191

193

105

195

197

81

193

680

199

603

115,161

276

203, 900

201

651

203
D'Arco, Ph.

Dahl, P.S.

Dal Negro, A.

Dalpé, C.

Dandurand, J-L.

Danyushevsky, L.V.

Darling, W.G.

David, F.

Davidson, J.P.

Davies, A.

Davison, P.

Davison, W.

de Caritat, P.

de Pablo-Galán, L.

de Wit, M.J.

Dearlove, J.P.L.

Debrabant, P.

Deines, $\mathrm{P}$.

Delgado, J.J.

Deloule, E.

DePaolo, D.J.

Dereje, A.

Derrick, S.

Deutsch, A.

Devey, C.W.

Devidal, J-L.

Dhakar, S.P.

Dia, A.N.

Diakonov, I.

Dick, H.J.B.

Dimas, G.

Ding, $\mathrm{K}$.

Dingwell, D.B.

Dinkel, C.

Dinsdale, A.

Dobrovolskaya, M.G

Dobrovolsky, E.V.

Dobson, B.R.

Dobson, $\mathrm{K}$.

Donahoe, R.J.

Dovesi, R.

Downes, $\mathrm{H}$.

Drake, M.J.

Draper, D.S.

Drever, J.I.

Driesner, $T$.

Drimmie, R.J.

Dubinin, A.V.

Duckworth, R.

Dulski, P.

Dunai, T.J.

Dunning, G.R.

Duthou, J.-L.

Edwards, A.

Eiler, J.M.
211

205

932

207

71,223

209

603

690

895

213

497

215,497

148,150

682

581

217

259

219

221

527,597

844

707

31

678

360

223

134

225

71,227

229

682

231

636

961

213

233

235

819

237

237

211

979

144

470

239

241

292

243, 883

774

61

245

977

732

247

924
El-Metwally, A.A.

Elderfield, $\mathrm{H}$.

Eldridge, C.S.

Ellam, R.M.

Elliott, T.E.

Ellis, D.J.

Elmore, D.

Elphick, S.

Elphick., S.C.

Elsenheimer, D.

Elthon, D.

Emmanuel, L.

Erel, Y.

Essawy, M.A.

Essene, E.J.

Fagel, N.

Falck, W.E.

Fallick, A.

Fallick, A.E.

Fallick, T.

Falloon, T.J.

Fanfani, L.

Farquhar, J.

Farrell, J.W.

Faure, G.

Fenwick, C.S.

Fernández-Nieto, C.

Ferry, J.M.

Figueiredo, M.O.

Finley, J.B.

Fischer, A.

Fisk, M.R.

Fitton, J.G.

FitzGerald, J.D.

Fitzsimons, I.C.W.

Fleet, M.E.

Fletcher, T.J.

Foley, S.

Foley, S.F.

Forde, E.J.

Fornari, D.J.

Förster, H.-J.

Forsythe, L.

Forsythe, L.M.

Fouillac, C.

Fozard, P.R.

Francois, R.

Franz, G.

Frape, S.K.

Fraser, D.G.

257

83

587

249

799

265

722

787

649

924

251,589

253

255

257

195

259

261

90

109,428 ,

583,593

914

209, 263

173

265

179, 267

268

776

339

90 
Frau, F.

Freedman, P.A.

Freer, R.

Frei, R.

Freitas, M.C.

Frey, F.A.

Frick, L.R.

Friend, C.

Fritz, B.

Fritz, S.J.

Frost, D.J.

Früh-Green, G.L.

Fryer, B.J.

Fujisawa, $\mathrm{H}$.

Furman, $\mathrm{T}$.

Furukawa, Y.

Gaetani, G.A.

Galer, S.J.G.

Galimov, E.M.

Gallagher, K.

Gallahan, W.E.

Gammons, C.H.

Gandhi, S.M.

Ganeshram, R.

Ganor, J.

García, R.

Garland, F.

Gascoyne, M.

Gasparik, T.

Gebauer, D.

Gehring, A.U.

George, M.T.

Geßmann, C.

Gezaegn, Y.

Ghiorso, M.S.

Gier, E.

Giese, U.

Gilmour, J.D.

Gisby, J.

Gíslason, S.R.

Glasser, F.P.

Gloor, M.

Goff, J.P.

Goldstein, S.J.

Goldstein, S.L.
301,354

303,304

305,813

307,394

653

309, 311

633

313

140,315 ,

619

21

317

319

321

936

323

325

327

707

418

858

329

331

213

27, 333,

752

29

13

983

335,844

3,165 ,

175,197 ,

304, 337,

360

González-López, J.M

Gorokhov, I.M.

Gout, R.

Gouveia, M.A.

Grachev, A.

341

223, 227

343, 744

21
Grady, A.E.

Graham, C.

Graham, C.M.

Graham, D.

Graham, D.W.

Graham, E.

Gray, D.R.

Green, D.

Green, D.H.

Gregory, R.T.

Grime, G.W.

Gromet, L.P.

Grönvold, K.

Grove, T.L.

Gurenko, A.A.

Guscott, S.

Gutiérrez-Mas, J.M.

Haase, K.M.

Hack, P.J.

Hall, A.J.

Hall, C.M.

Hall, R.

Hallbauer, D.K.

Halliday, A.N.

Hammouda, T.

Hanan, B.B.

Hannington, M.D.

Hanson, G.N.

Harðarson, B.S.

Harlavan, Y.

Harper Jr., C.L.

Harris, J.W.
Harley, S.L.

Harmon, R.S.

Harris, N.

Harris, N.B.W.

Hart, S.R.

Harte, B.

Harvey, F.E.

Hascall, $\mathrm{K}$.

Hattori, K.

Hauri, E.H.

Hawkesworth, C.

Hawkesworth, C.J.

949

187,345

924

297

347,370

237

352

349

209, 263,

350,996

352

983

179

676,848

301,354

356,860

545

358

360

653

583

366

282

362,364

366

368

370

438

103

272,372

255

374

376

378

219,384 ,

386,535

380

55

382

167, 345,

384,386 ,

388, 981

292

651

142, 390

392

317,394 ,

396,432 ,

879,916

55, 479,

Hayashi, K.

Heaman, L.M.

Hein, J.R.

Heinrich, W.

290

136
Helffrich, G.

986

Helgeson, H.C.

736

Hellmann, R. $\quad 400$

Helmers, H. $\quad 975$

Heming, G.

402

Henderson, C.M.

Henderson, G.M.

Henderson, G.S.

819

404,406

Hensen, B.J.

Hergt, J.M.

408

Hesse, R.

Higgs, N.C.

Hinton, R.W.

Hirdes, W.

Hirschmann, M.M.

Hoal, B.G.

Hoal, K.E.O.

Hoefs, J.

Hoering, T.C.

Hoernes, $S$.

Hoernle, K.

Hoffbauer, R.

Hofmann, A.W.

410,412

414

922

898,900

416

499

418

703

703

376, 973

740

73, 893

971

893

165,304 ,

337,420 ,

452,537 ,

718,764

Holden, P.

895

Holdham, M.T.

422

Holland, H.D.

Holm, N.G.

Holness, M.B.

Hooker, P.J.

Horn, I.

Hovey, J.

Huang, Y.-M.

Hudon, P.

Huizenga, J.M.

Humayun, M.

Humphris, S.E.

Hunter, R.H.

Hurwitz, S.

Hutcheon, I.

Hutchison, M.T.

Hypolito, R.

398,424

17,426

428

603, 965

430

65

432

434

436

177

438

569

440

150

386

887

Inger, S.

758

Ingri, J.

Irifune, $\mathrm{T}$.

Ishibashi, J.

Iwamori, $\mathrm{H}$.

442

444

797

446

Jackson, S.E.

280,430

Jacob, D.E.

448 
Jamet, $P$.

Jaques, A.L.

Jarvis, I.

Jarvis, $\mathbf{K}$.

Jarvis, K.E.

Jebb, $M$.

Jenner, G.A.

Jochum, K.P.

Johnson, K.T.M.

Johnston, A.D.

Johnston, C.

Jones, C.E.

Jordaan, L.J.

Joron, J.L.

Jostons, A.

Kadik, A.A.

Kalinowski, B.

Kamenetsky, V.S.

Kaminski, E.

Kaminsky, F.V.

Kaminsky, W.

Kanayama, S.

Karpoff, A-M.

Karup-Moller, S.

Kastner, M.

Kelemen, P.B.

Keller, J.

Kelley, S.

Kelley, S.P.

Kemp, A.J.

Kent, R.

Kerstein, L.

Kersting, A.B.

Kesson, S.E.

Kilian, R.

King, P.M.

Kinny, $P$.

Kirkley, M.B.

Kinzler, R.J.

Klammer, D.

Klápová, $\mathrm{H}$.

Klein, M.

Knott, R.

Koeberl, C.

Kohn, M.J.

Kohn, S.C.

Kokarev, S.G.

Kolodny, Y.

Konzett, J.

Korkiakoski, E.

Korkmaz, S.

Kotková, J.

Kovács, L.Ó.
551 Kravchuk, I.F.

263 Krom, M.D.

349, 422, Kronfeld, J.

638

349

422

914

280,430

452

454

653

292

366

456

9

458

460

817

199, 462

9

813

981

797

295

51

700

464,466

840

879,930

468,470

525,752

471

317

473

458,475

477

479

345,481

388

354, 483,

569

485

996

487

774

811

924

489

669

557

491

509

493

494

934
Kroon, D.

Krupp, R.E.

Kudrjavtseva, G.P.

Kuo, P.H.

Kurt, $\mathrm{H}$.

Kurz, M.D.

Kushiro, I.

Labeyrie, L.D.

Lahtinen, $\mathrm{R}$.

Lam, $P$.

Lambert, D.D.

Langmuir, C.H.

Lanyon, $\mathrm{R}$.

496

497

529

31

499, 501

448

424

493

392

503

Lasaga, A.C.

Laue, H.-J.

Le Forestier, L.

Lea, D.W.

Lee, D.-C.

Lee, M.R.

Lee, $\mathrm{S}$.

Leelanandam, C.

Leśniak, P.M.

Lestinen, P.

Levy, D.B.

Lewis, A.J.

Libourel, G.

Litvinovsky, B.A.

Liu, C.

Livnat, A.

Lloyd, F.E.

Lo Mónaco, S.

Longstaffe, F.J.

López-Galindo, A.

Lottermoser, B.G.

Lowry, D.

Lu, D.M.

Luais, B.

Luck, J.-M.

Lussiez,, P.

Luster, J.

Luth, R.W.

Luz, B.

Lyakhovsky, V.

Lyon, I.C.

288

789

290

337, 511

199

140, 315,

619,992

304

519,877

513

366

690

515

517

521

509

523

525

519, 527,

877

969

237

529

776

619

150

339, 358,

531

533

448,535 ,

573,945

537

9, 99,

539

77,541

565

323

543

557

440

545
MacDonald, D.I.M.

613

Macdonald, $\mathbf{R}$.

916

MacGregor, $\mathbf{R}$.

779

Macpherson, C.G.

Madé, B.

535,573

547, 549,

Maiwald, U.

551

Makovicky, E.

553

Makovicky, M.

Manning, C.E.

Manning, D.A.C

Mantovani, M.

Markel, D.

Marr, R.A.
Marriner, G.

Martel, D.J.

Martin, R.F.

Marty, B.

Martínez-Ruíz, F.

Massey, J.

Massey, J.A.

Masuda, A.

Mathez, E.A.

Matsui, M.

Mattey, D.

Mattey, D.P.

Matthews, A.

Mattle, N.

Maurice-Johnsson, P.A. $\quad 575$

May, F.

577

Mazzucchelli, M.

McBeath, M.M.

McCandless, T.E.

McDonald, I.

McGill, R.A.R.

McKeever, P.J.

McKenzie, D.

McKenzie, J.A.

McKibben, M.A.

McLennan, S.M.

McMillan, J.W.

Medvedev, A.I.

Meen, J.K.

Meier, M.

Meisel, T.

Melezhik, V.A.

Melnikov, N.N.

Menzies, $M$.

Menzies, M.A.

Merceron, $\mathrm{T}$.

Merino, E.

Metcalf, $\mathbf{R}$.

Metcalfe, R.

537

156

579

581

583

545

446, 471,

585,768 ,

848

295, 561

587

103

81

617

589

92

591

593

341

42

167,595

801

597,599 
Metz, P.

Meunier, A.

Mezger, $\mathrm{K}$.

Michael, P.J.

Michard, G.

Michel, C.

Miller, D.M.

Miller, S.

Milodowski, A.E.

Minarik, W.G.

Mitchell, C.

Mogollón, J.L.

Möller, A.

Molzahn, M.

Monaco, P.

Montel, J.-M.

Moreira, M.

Mörth, C-M.

Mossmann, J.R.

Mountain, B.W.

Mountfort, S.A.

Mountjoy, E.W.

Mozgova, N.N.

Müller, B.

Müller, P.J.

Müller-Sigmund, H.D.

Mungall, J.E.

Murphy, A.

Murphy, K.M.

Murphy, M.D.

Murray, D.W.

Murray, J.W.

Murrell, M.T.

Murton, B.

Muzuka, A.N.N.

Nabelek, P.I.

Nahon, D.

Nakai, S.

Natland, J.

Navon, O.

Ngwenya, B.T.

Nielsen, R.L.

Nishiizumi, K.

Nishri, A.

Nixon, P.H.

Nocchi, $M$.

Nordstrom, D.K.

Novak, M.

Nowack, B.

Noy, D.J.

Nägler, Th.

Nägler, Th.F.

$\begin{aligned} 1002 & \text { O'Hara, M.J. } \\ 36 & \\ \text { 195, 304, } & \text { O'Neil, J.R. } \\ 605,621, & \text { O'Nions, R.K. } \\ 623 & \end{aligned}$

370,607

609

611

337

215, 613

965

615

249,617

619

621

623

684

732,940

627,874

442

801

629,631

81

686

633

961

809

634

636

638

239

639

15

313

335,844

774

641,643

645

599

7, 709

229

440,813

649

651,653

268

557

703

684

270

655

838

59

591

647

Oberthür, Th.
Palmer, M.R.

Palomo, I.

Paquette, J.

Parisi, G.

Parker, S.C.

Parkinson, I.J.

Parsons, I.

O'Sullivan, G.

Oberli, F.

Oberti, R.

ddone, $\mathrm{M}$.

Odling, N.W.A

Ohmoto, $\mathrm{H}$

Okay, A.I.

Okrugin, V.M.

Okrugina, A.M.

Olive, V.

Oloriz, F.

Osanai, Y.

Oskarsson, N.

Ostermann, $\mathrm{M}$.

Paterson, B.A.

Patiño Douce, A.E.

Pattison, D.R.M.

Pauwels, $\mathrm{H}$.

Pawley, A.R.

Paytan, A.

Pearce, J.A.

Pearce, J.M.

Pearson, D.G

Pearson Jr., F.J.

Peate, D.W.

Peccerillo, A.

Pedersen, T.F.

Pekdeger, A.

Pelton, A.D.

Pérez, D.A.

Pérez, N.M.

Perfit, M.R.
661, 663, Perutz, R.N.

665, 667 Peterman, Z.E.

193

221 Peters, M.T.

711,953

136, 185, Petit, J.-C. 715

404, 406, Petrov, V.A. 872

673, 1004 Peucker-Ehrenbrink, B. 718

680 Philippot, P. $\quad 720$

92 Phillips, F.M. 722

499 Phillips, M.W. 740

$998 \quad$ Phinney, D.L. 121

674 Piccardo, G.B. $\quad 756$

657 Piccirillo, E.M. 932

659 Pichavant, M. 368

398 Pierre, C. 32, 724

468 Pin, C. 732

669, 670, Pitkänen, P. $\quad 726$

671, 672 Plettinck, S. $\quad 728$

669, 670, Podlaha, O.G. $\quad 730$

671 Poitrasson, F. 732

249 Pokhilenko, N.P. 831

Pokrovski, G. 71, 227,

563,674 ,

684

410

676

678

912, 932,

998

Pokrovskii, V.A.

734

Pokrovsky, O.S. $\quad 738$

Polushin, S.V. $\quad 670$

Poon, D. 161

Popp, R.K. $\quad 740$

Postma, D. $\quad 742$

Potts, G.J. $\quad 910$

Prell, W. 15

5, 525, Price, G.D. 944, 963

776 Prozesky, V. 885

563, 674, Prudêncio, M.I. 343, 744

684 Przybylowicz, W. 885

686 Pudlo, D. 746

684 Pueyo, J.J. 32, 724

688, 944 Putlitz, B. 748

701

690

416,770

Quattrocchi, F.

750

694

36, 696

698

700

701

59,779

703,705

609

701

707

267,313

553

434

619

709

335
Ragnarsdottir, K.V. $\quad 5,752$,

Raith, M.

926

Rämö, O.T.

119,327

Ramos, F.C.

Rampone, E.

Ramsbotham, W.

Rapp, R.P.

Rauch, U.

Ravizza, G.

Read, D.

Reddy, S.M.

754

766

756

758

760

95

718

762

325

Reeder, S.

Reeves, S.J.

158

290

Refson, K. 


$\begin{array}{lr}\text { Rehkäper, M. } & 764 \\ \text { Reid, M.R. } & 766 \\ \text { Reisberg, L. } & 623 \\ \text { Renard, M. } & 253 \\ \text { Reusser, E. } & 918 \\ \text { Rex, D. } & 758 \\ \text { Rey, P. } & 197 \\ \text { Richardson, C. } & 768 \\ \text { Riciputi, L.R. } & 770 \\ \text { Rickard, D. } & 772, \\ \text { Riley, T.R. } & 774 \\ \text { Rivalenti, R. } & 537 \\ \text { Roberts, H.H. } & 38 \\ \text { Robinson, D. } & 601 \\ \text { Robinson, J.A.C. } & 778 \\ \text { Rochelle, C.A. } & 779 \\ \text { Rock, P.A. } & 156 \\ \text { Rodriguez-Navarro, C. } & 781 \\ \text { Rodriguez-Tovar, F.J. } & 531 \\ \text { Rogan, W. } & 783 \\ \text { Rogers, N.W. } & 479,703, \\ & 785 \\ \text { Rohrlich, V. } & 253 \\ \text { Ron, H. } & 255 \\ \text { Rona, P.A. } & 438 \\ \text { Rose-Hansen, J. } & 51 \\ \text { Rosenbaum, J.M. } & 787,979 \\ \text { Rosenhauer, M. } & 448 \\ \text { Rosenthal, Y. } & 789 \\ \text { Ross, N.L. } & 963 \\ \text { Rossi, Ph. } & 181 \\ \text { Ruiz, J. } & 579 \\ \text { Rumble, D. } & 90 \\ \text { Ruotsalainen, P.H. } & 791 \\ \text { Russell, M.J. } & 109 \\ \text { Ryabchikov, I.D. } & 793 \\ \text { Ryckman, D.A. } & 754 \\ \text { Rye, R.O. } & 424 \\ & \\ & \end{array}$

Sackett, W.M.

Sakai, H.

Salignac, A.-L.

Salminen, R.

Salters, V.J.M.

Sandiford, M.J.

Sandrone, G.

Sandström, $\mathrm{H}$.

Sanjuan, B.

Sano, Y.

Santosh, M.

Sarda, $\mathrm{Ph}$.

Sardini, P.

Satir, M.

Saunders, A.D.

Saunders, V.R.

Savage, D.
Savin, A.

Savolainen, $\mathrm{H}$.

Sawyer, E.W.

Saxton, J.M.

Scarfe, C.M.

Schaaf, P.

Schaller, $T$.

Schärer, U.

Scheepers, R.

Schenk, V.

Schiano, P.

Schilling, J.-G.

Schliestedt, M.

Schmid, R.

Schmincke, H-U.

Schmincke, H.-U.

Schneider, R.R.

Schosseler, P.M.

Schott, J.

Schrauder, M.

Schwartzman, D.

Schweda, P.

Seal, II, R.R.

Sears, S.K.

Sebastian, E.

Seck, H.A.

Semet, M.

Sequeira Braga, M.A.

Sergeyev, A.

90

791

109

754

424

Seyfried, Jr., W.E.

Sharp, M.

Shaw, H.F.

Shcherbakov, Yu.G.

Shelley, J.M.G.

Shen, A.H.

Shengrong, L.

509

801

709

55

627

891,1002

272

211

59,779
Seward, T.M.

Shackleton, N.

Shackleton, N.J.

Shaffer, E.E.

Shanks, III, W.C.

Shikazono, N.

Shilobreeva, S.N.

Shimizu, D.

Shimizu, N.

842

509

105

545

543

803

805

678

456

621

807

627

748

936

971

57

809

323

71,227 , 659,734

811,813

815

817

79

922

781

487, 981

9

744

734

65,75 ,

241,629 ,

819

79,231

83

404

713

79

908

121

821

475

823

825

827

460

887

466,487 ,

807,829 ,

831,848 ,

860,862 ,

889

Shimmield, G.

Shimmield, G.B.

Shirey, S.B.

914

31,649

705,833 ,

835,971

837

Sholkovitz, E.
Shuvalov, R.A.

669,671 ,

Sigg, L.

672

Sigmund, J.

838

840

Sigvaldason, G.E.

676

Silvi, B.

Sims, K.W.W.

Skelton, A.D.L.

Slater, L.

Small, J.S.

Smith, A.D.

Smith, I.

Smith, M.

842

844

846

848

850,852

854

432

856

Snee, L.

Snellman, M.

42

726

Snellman, M.V.

791

858

705

Snyder, G.A.

Sobolev, A.V.

57, 209,

462,860 ,

862

Sobolev, N.V.

Sobolev, R.N.

Sopaheluwakan, J.

Soulard, H.

Spear, F.S.

Spears, D.A.

Spicuzza, M.J.

Spiering, B.

Spiro, B.

Starostin, V.I.

Staudacher, T.

Staudacher, Th.

Stefanov, J.M.

Stein, $M$.

Stepanov, I.I.

Stern, Ch.

Sterpenich, J.

Stewart, K.

Stillings, L.

Stoffers, P.

Stolper, E.M.

Stone, W.E.

Storey, M.

Stosch, H.G.

Strauss, $\mathrm{H}$.

705,831

864,872

975

866

868

515,870

924

327

529, 951

872

14

627,874

671

255,420

671, 672,

876

477

877

879

117

360

44, 418

276

414

487

881

883

711

501

Stuckless, J.S.

25

243

Sval'nov, V.N.

491, 885

872

813

887

Szikszay, M. 
Taberner, $\mathrm{C}$.

Takazawa, E.

Tanguy, J.C.

Tarney, J.

Taubald, $\mathrm{H}$.

Taylor, L.A.

Teagle, D.

Teagle, D.A.H.

Tegtmeyer, A.

Tennie, A.

Tepley, F.J.

Thirlwall, $\mathrm{M}$.

Thirlwall, M.F.

Thompson, A.B.

Thompson, G.

Thompson, J.

Thompson, $\mathrm{P}$.

Thomson, J.

Thöni, M.

Thorvaldsson, $\mathrm{T}$.

Tischendorf, G.

Titiloye, J.O.

Tivey, M.K.

Todt, W.

Toledo, M.C.M.

Toplis, M.J.

Torres-Ruíz, J.

Torssander, $\mathrm{P}$.

Tossell, J.A.

Touret, J.L.R.

Tranter, $M$.

Treloar, P.J.

Tribuzio, R.

Trommsdorff, V.

Trull, $\mathrm{T}$.

Tsunogai, U.

Tudhope, S.

Turchenko, T.L.

Turner, G.

Turner, S.

Tüysüz, N.

Ulmer, $\mathbf{P}$.

Upton, B.

Urquiola, M.M.

Urusov, V.S.

Vaasjoki, M.

Vaillancourt, J.

Vali, $\mathrm{H}$.

Valley, J.
32,72

889

565

414

891

705

366

88

304

893

895

42

282

491

438

349

897

898,900

902

752

284

688

438

197

887

527

339

442

904

436, 906

908

910

912

918

565

797

914

341

331,545

317,394 ,

396, 879,

916

493

491,918

9
724

920

754

40

686, 922

345
Valley, J.W.

Vallius, $\mathrm{H}$.

Valsami-Jones, E.

Van Baalen, M.R.

Van Bergen, M.J.

van Breemen, $\mathrm{O}$.

van Calsteren, $\mathrm{P}$.

van der Pluijm, B.

van der Laan, S.R.

van Moort, J.C.

Vance, D.

Vannucci, R.

Varne, R.

VarsáNy, I.

Vavra, G.

Veizer, J.

Venemann, T.

Verma, S.P.

Vielzeuf, D.

Vikentyev, I.V.

Vikentyev, V.

Vinogradov, V.I.

Virgo, D.

Vočadlo, L.

Volkov, A.B.

Vroon, P.Z.

Vry, J.K.

Wada, M.

Wagner, T.P.

Wai, K.M.

Wakefield, S.

Wakita, H.

Walder, A.J.

Waldron, K.A.

Walker, L.

Wall, A.

Wall, F.

Wallin, B.G.K.

Walling, E.M.

Walraevens, $\mathrm{K}$.

Wang, D.

Wang, Y.

Waters, D.J.

Watson, G.W.

Watt, G.R.

Wedepohl, K.H.

Wefer, G.

Wegener, $M$.

Wehrli, B.

Wentzcovitch, R.M.
924

509

926

928

945

105

432, 916

195

505

625

34,930

756,912 ,

932, 998

199

934

936

126, 128 ,

730

221

938

940

233

107

942

740

944

872

282,945

154

947

392

949

680

709, 797

366

690

690

944

951

953

156

146, 955

183

597, 599 ,

599

957

688

152

959

809

304

805,961

963
West, J.M.

Wetton, P. 779

Wheeler, J. $\quad 910$

White, A.F. $\quad 967$

Wickham, S.M. $\quad 969$

Widom, E. $\quad 971$

Wiechert, U. 973

Wieder, R.K. $\quad 655$

Wijbrans, J.R. $\quad 975$

Williams-Jones, A.E. 309, 311,

Williams, S.N. $\quad 709$

Wilson, M. $\quad 979$

Wilson, M.R. $\quad 977$

Wilson, T.R.S. $\quad 900$

Witt-Eickschen, G. $\quad 981$

Wogelius, R.A. $\quad 983$

Wollast, R. $\quad 728$

Wood, B. 213

Wood, B.J. 101, 294,

698,778 ,

866,985 ,

986

Wood, S.A. $\quad 311$

Woodhead, J.D. $\quad 988$

Wörner, G. 623

Wright, K. $\quad 990$

Wu, P. 434

Wu, T.-W.

278

Xiao, Y.

992

Xue, $\mathrm{H}$.

838

Yardley, B.W.D. $\quad 856,994$

Yaxley, G.M. $\quad 996$

Yi, W. 366

Yoder Jr., H.S. $\quad 740$

Yu, E.-F. 288

Yu, Y.

309

Zanetti, A.

756, 998

Zanvilevich, A.N. $\quad 969$

Zhang, $\mathrm{H}$.

215,497

Zheng, Y.-F.

1000 ,

Zhenmin, G.

1002

Zhou, B.

Zhu, X.K.

Zinngrebe, E.

Zverev, V.P.

825

412
1004

1006

1008 


\section{SUBJECT INDEX}

Papers are listed under subject headings based on symposia organised for the Goldschmidt Conference in Edinburgh in August-September, 1994. Sub-headings are used for the larger symposia, and often these sub-headings cover material which overlaps several symposia. The subject headings and their research areas are briefly outlined below, and these are followed by listings of the papers in alphabetical order under each subject heading or sub-heading.

1. Theoretical geochemistry - applications of theoretical mineral physics to mineral chemistry and element distribution, including aspects of diffusion; $a b$ initio methods.

2. Experimental geochemistry - laboratory experimental studies across the full spectrum of P-T conditions.

3. Geochemical techniques - developments in instrumentation and techniques; special applications and programmes.

4. Weathering and erosion, deposition and diagenesis - geochemical processes in low temperature rock degradation and genesis.

5. Groundwater chemistry and palaeohydrology - geochemical characterisation of groundwater systems and of time dependent hydrogeological changes, significance to palaeoenvironments, prognoses of future changes.

6. Waste containment and pollutant transport - geochemical assessment of the contols and risks of all types of waste and pollutant disposal.

7. Ocean composition and fluxes during the Quaternary - high resolution documentation of changes in marine geochemistry, and geochemical indicators of recent events.

8. Ocean palaeochemistry and the evolution of the ocean basins - the gocchemistry of ocean evolution in the pre-Quaternary.

9. Modern submarine hydrothermal processes - contols on the geochemical reactions within sub-seafloor hydrothermal systems, and their spatial and temporal variability.

10. Mechanisms of isotopic and chemical communication in crust and mantle rocks - application of new microanalytical (ion and laser probe) techniques to constrain micron to millimetre scale processes in rocks, and their relevance to macroscopic studics of mass and heat transport.

11. Partitioning of elements - new data on partition coefficients for mineral, melt, fluid phases as determined by experiment or measurement of natural phases; including aspects of the distribution of precious metals.

12. Dehydration, partial melting and fluid distribution in the crust - covering both the geochemistry of high-temperature processes in the continental crust and the modification of crust undergoing subduction.

13. Magma generation processes - geochemical evidence of the generation and evolution of mantle-derived melts.

14. Mantle development in space and time - geochemical and mineralogical information on mantle constitution.

15. Geochronometry and thermal history - quantitative thermal histories of rocks and metamorphic belts. 


\section{Theoretical geochemistry}

D'Arco, P, Sandrone, G, Dovesi, R, Saunders, V R

Edwards, A, Freer, R, Catlow, C R A

Made, B J A D

Matsui, $M$

Parker, S C

Silvi, B, Savin, A

Tossell, J A

Vocadlo, L, Wall, A, Parker, S C, Price, G D

Wentzcovitch, R M, Ross, N L, Price, G D

Wright, K, Freer, R, Catlow, C R A

Xiao, Y, Lasaga, A C

Zheng, Y-F
$\mathrm{Ab}$ initio study of the relative stability under pressure of $\mathrm{MgSiO}_{3}$-ilmenite, -perovskite, and (periclase + stishovite)

Combined experimental and computer simulation studies of cation diffusion in silicate garnets

Empirical relations to estimate kinetic constants of silicates

A transferable interatomic potential model for crystals and melts in the system $\mathrm{CaO}-\mathrm{MgO}-\mathrm{Al}_{2} \mathrm{O}_{3}-\mathrm{SiO}_{2}$

Atomistic simulation studies of mineral surfaces and the role of impurities on their structure and stability

Chemical bonds in minerals: Topological analysis of the electron localization function

Theoretical studies of the speciation of $\mathrm{Sb}$ in sulphidic solutions

Absolute ionic diffusion in $\mathrm{MgO}$ : computer calculations via lattice dynamics

$\mathrm{Ab}$ initio constant pressure molecular dynamics study of silicate perovskites

Oxygen diffusion and water-related defects in feldspar minerals: information from experimental and modelling studies

Applications of ab initio quantum mechanical potential surfaces to mineral physics calculations

Oxygen isotope fractionation in metal monoxides

\section{Experimental geochemistry}

2a. Experimental constraints on melting in the mantle

See listing under section $13 a$

\section{2b. Acidic and other melts and fluids at high $P$ and $T$}

Baker, D R, Vaillancourt, J

Ballhaus, $\mathrm{C}$

Blencoe, J G

Davies, A, Wood, B J, Barry, T, Dinsdale, A, Gisby, J

Frost, D J, Wood, B J

Gessmann, C, Spiering, B, Raith, M

Henderson, G S, Fleet, M E

Hudon, P, Baker, D R, Pelton, A $\mathrm{D}, \mathrm{Wu}, \mathrm{P}$

Hurwitz, S, Lyakhovsky, V, Navon, $\mathrm{O}$

Kadik, A A, Shilobreeva, S, Vernadsky, V

Kohn, S C, Brooker, R A

Konzett, J, Ulmer, P, Sweeney, R J, Thompson, A B

Luth, R W

Manning, C E
The viscosity of $\mathrm{F}+\mathrm{H}_{2} \mathrm{O}$-bearing peralkaline and peraluminous rhyolitic melts

$\mathrm{C}-\mathrm{H}-\mathrm{O}$ fluid speciations under mantle conditions

Calculated activities for species in albite-water melts

The thermodynamics of mineral-melt equilibria in the system $\mathrm{CaO}-\mathrm{MgO}-\mathrm{Al}_{2} \mathrm{O}_{3}-\mathrm{SiO}_{2}$

Carbon dioxide fugacities at high temperature and pressure

Experimental investigation of the Fe-Mg-partitioning between garnet and biotite with respect to the influence of $\mathrm{Ti}$ in biotite

The structure of Ti-silicate glasses by Raman spectros-copy: Implications for the role of $\mathrm{Ti}$ in natural melts

Disappearance of the liquid-liquid miscibility gap in the system $\mathrm{CaO}-\mathrm{MgO}-\mathrm{SiO}_{2}$ at high pressure

Diffusive growth of water bubbles in rhyolitic melts

The primary carbon and the formationof carbon species in terrestrial magmas

The effect of water on the solubility and speciation of $\mathrm{CO}_{2}$ in aluminosilicate glasses along the join $\mathrm{SiO}_{2}-\mathrm{NaAlO}_{2}$

Phase relations and chemistry of richteritic amphiboles in the system $\mathrm{K}_{2} \mathrm{O}-\mathrm{Na}_{2} \mathrm{O}-\mathrm{CaO}-\mathrm{MgO}-\mathrm{Al}_{2} \mathrm{O}_{3}-\mathrm{SiO}_{2}-\mathrm{H}_{2} \mathrm{O}$ (KNCMASH)

Carbonation reactions in eclogites at high pressure: implications for carbonic fluids in the mantle

Experimental determination of the solubilities of quartz, kyanite and corundum in $\mathrm{H}_{2} \mathrm{O}$ in the lower crust and mantle 
Marr, R A, Baker, D R, Williams-Jones, A E

Mungall, J E, Dingwell, D B

Popp, R K, Virgo, D, Yoder, $\mathrm{H}$ S, Hoering, T C, Phillips, M W

Shen, A H, Chou, I, Bassett, W A

Snyder, D, Gier, E, Carmichael, I

Thompson, $\mathrm{P}$

Wood, B J, Brodholt, J P
Alkali zirconosilicate speciation in halogen-rich, felsic, peralkaline magmas

Effects of water content, temperature and pressure on actinide tracer diffusion in melts of haplogranitic composition

The role of hydrogen fugacity in controlling Ferric-Ferrous ratio and volatile content of Kaersutitic amphibole : an experimental study

Experimental determination of PVTX relations of fluids in the diamond-anvil cell

Experimental measurements of the thermal conductivity of molten silicates

The sanidine - 'sanidine hydrate' reaction boundary

The density of water to $25 \mathrm{kbar} / 1873 \mathrm{~K}$

\section{2c. Mantle mineralogy and the transition zone}

Gasparik, T

Harte, B, Harris, J W

Harte, B, Hutchison, M T, Harris, J W

Irifune, $\mathrm{T}$

Kesson, S E, FitzGerald, J, Shelley, J M

Pawley, A R, Wood, B J

Ulmer, P, Trommsdorff, V, Reusser, E

Wood, B J, Helffrich, G
Experimentally determined melting relations in simple and complex chemical systems at pressures up to $23 \mathrm{GPa}$

A review of natural mineral assemblages from the mantle transition zone

Trace element characteristics of the lower mantle - An ion probe study of inclusions in diamonds from Sao Luie

Phase transformations in pyrolite and subducted crust compositions down to a depth of $800 \mathrm{~km}$ in the lower mantle.

Phase relations for the former basaltic crust of the slab in the perovskitite facies of the lower mantle

Talc dehydration to 50 kbar: constraints on the volume of $\mathrm{H}_{2} \mathrm{O}$ at high pressure

Experimental investigation of antigorite stability to $80 \mathrm{kbar}$

Mantle stratification: constraints from mineral physics, seismological and phase equilibrium data

\section{2d. Mineral dissolution, interfaces and hydrothermal solutions}

Azaroual, M, Pauwels, $\mathrm{H}$, Mcunier, A, Sardini, $\mathrm{P}$

Bateman, K, Noy, D J, Pearce, $\mathrm{J}$ M, Savage, D

Bebie, J, Hovey, J, Seward, T M

Benezeth, P, Diakonov, I, Pokrovski, G, Dandurand, J J, Schott, J

Benning, L G, Seward, T M

Casey, W H, Rock, P A, McBeath, M M, Walling, E M, Chung, J-B

Devidal, J-L, Dandurand, J-L, Gout, $\mathrm{R}$

Diakonov, I, Pokrovski, G, Castet, S, Schott, J, Gout, R

Finley, J B, Nordstrom, D K

Fouillac, C, Azàroual, M

Gammons, C H, Williams-Jones, A E, Yu, Y
Fluid flow equipment for hydrothermal investigations: apparatus and preliminary results

Coupled flow and reaction: a modelling and experimental study of zeolite diagenesis

Thallium (1) chloride complexing in aqueous media to $200^{\circ} \mathrm{C}$

Gallium solubility and aqueous speciation in hydrothermal solutions $\left(60-125^{\circ} \mathrm{C}\right)$. Experimental study and comparison with aluminium

Hydrosulphide complexes of gold (I) at high pressures and temperatures: equilibrium and kinetic problems

A new method for determining excess Gibbs energies in binary metal-carbonate solid solutions

Solubility of kaolinite in alkaline solutions at hydrothermal conditions

Experimental study of $\mathrm{Na}-\mathrm{Al}$ complexing in hydrothermal solutions

Evaluation of the chemical model in WATEQ4F: 1 . The major ion activity coefficients - $\mathrm{Na}, \mathrm{K}, \mathrm{Ca}, \mathrm{Mg}, \mathrm{Cl}$

Comparison between actual and theoretical dissolution rates in a granite-water interaction experiment at $180^{\circ} \mathrm{C}$ and $14 \mathrm{bar}$

New data on the stability of gold(I) chloride complexes at $300^{\circ} \mathrm{C}$ 
Gammons, C H, Wood, S A, Williams-Jones, A E

Gehring, A U, Schosseler, P M, Luster, J

Hellmann, $\mathbf{R}$

Merino, E, Wang, Yutian, Wang, Yifeng, Nahon, D

Mountain, B W, Seward, T M

Oelkers, E H, Schott, J

Pokrovski, G, Schott, J, Sergeyev, A

Pokrovskii, V A, Helgeson, H C

Rochelle, C A, Bateman, K, MacGregor, R, Pearce, J M, Savage, D, Wetton, $\mathrm{P}$

Seward, T M, Henderson, C M B, Charnock, J M, Dobson, B R

Small, J S, Manning, D A C

Small, J S, Manning, D A C

Valsami-Jones, E, Bailey, E H, Ragnarsdottir, K V

Wogelius, R A, Refson, K, Fraser, D G, Goff, J P, Grime, G W

\section{2e. Stable isotope partitioning.}

Bezmen, N I

Cole, D R

Driesner, T, Seward, T M

Rosenbaum, J M, Mattey, D P, Elphick, $\mathrm{S}$

Tennie, A, Hoffbauer, R, Hoernes, S

Zheng, Y-F, Metz, P, Satir, M
Experimental investigation of the stability of neodymium chloride complexes at $300^{\circ} \mathrm{C}$

The chemical form of $\mathrm{Mn}$ (II) and $\mathrm{V}$ (IV) in mineral phases as determined by EPR spectroscopy

A leached layer hydrolysis model: A better way to understanding feldspar dissolution at elevated temperatures and pressures

Implications of pseudomorphic replacement for reactiontransport modelling in rocks

The solubility of sparingly-soluble minerals at $25^{\circ} \mathrm{C}$ using a flowthrough column

Experimental study of kyanite dissolution rates as a function of $\mathrm{Al}$ and $\mathrm{Si}$ concentration

Determination of the sodium-borate association constant $\mathrm{NaB}(\mathrm{OH})_{4}^{\circ}$ between 75 and $200^{\circ} \mathrm{C}$ using new sodium selective glass electrodes

Calculation of the effect of $\mathrm{KAl}(\mathrm{OH}) \mathrm{O}_{4}$ formation on the solubility of corundum at high pressures and temperatures

Migration of cement pore fluids from a radioactive waste respository: Experimental studies of chlorite dissolution rates

A synchrotron EXAFS study of hydrothermal $\mathrm{AgNO}_{3}$ solutions

Competition between metal-carboxylate complexing, mineral precipitation, and carboxylate decomposition reactions

On-line monitoring of clay mineral precipitation in sandstone porespace under flow conditions

Experimental investigation of the solubility of uranium (VI) under hydrothermal conditions

Hydration reactions at the mineral-fluid interface: Experimental and computational studies

The above liquidus inhomogenity and cluster differentiation of fluid magmatic melts

Oxygen isotope exchange rates in mineral-fluid systems: correlations and predictions

Effects of dissolved salts on calcite-water oxygen stable isotope fractionation at elevated temperatures and pressures

Equilibrium garnet-calcite oxygen istope fractionation

Experimental determination of the oxygen isotope fractionations in the systems kyanite-calcite and talc-carbonate-water

Experimental calibration of oxygen isotope fractionation between calcite and tremolite in the presence of $\mathrm{CO}_{2}-\mathrm{H}_{2} \mathrm{O}$ fluid and a new data processing method for three phase systems

\section{Geochemical techniques, instrumentation and special applications.}

Galer, S J G, Laue, H-J, Goldstein, S L, Mezger, K, Hofmann, A W

Hallbauer, D K
Concept of a new thermal isotope mass spectrometer

Geochemical trace element analysis for ionic species by capillary electrophoresis 
Halliday, A N, Lee, D-C, Christensen, J N, Yi, W, Hall, C M, Jones, C E, Teagle, D, Walder, A J, Freedman, P A

Holdham, M T, Jarvis, I

Lahtinen, R, Lestinen, $\mathrm{P}$, Korkiakoski, E, Salminen, R, Sandstrom, H, Savolainen, $\mathrm{H}$, Vallius, $\mathrm{H}$

Petit, J-C

Sackett, W

van Moort, J C
I.C.P. magnetic sector multicollector mass spectrometry and its applications to geochemistry

A new method for the determination of the platinum group elements in sedimentary materials

Rock geochemistry research project (RGRP) in the Geological Survey of Finland

Applying $\mathrm{MeV}$ ion beam techniques to geochemical issues: Cross-fertilizing nuclear physics and geosciences

The utility of sediment pyrolysis

The chemical composition and paramagnetism of auriferous quartz

\section{Weathering and erosion, deposition and diagenesis}

4a. Early diagenesis

Albrecht, A, Beer, J

Bailey, A M, Roberts, $\mathrm{H} \mathrm{H}$, Blackson, J H

Burdige, D J, Dhakar, S P

Coleman, $\mathrm{M}$

Cundy, A B, Croudace, I W

Davison, W, Zhang, H, Miller, S

Donahoe, R J, Liu, C, Dobson, $\mathrm{K}$, Graham

Furukawa, Y, Barnes, $\mathrm{H} \mathrm{L}$

Gonzalez-Lopez, J M,

Fernandez-Nieto, C, Lopez-

Galindo, A, Torres-Ruiz, J

Holdham, M T, Jarvis

Ingri, J, Torssander, $\mathrm{P}$, Andersson, P S, Morth, C-M

Krom, M, Davison, P, Zhang, H, Davison, W

Krupp, R E, Suleimenov, O M

Luck, J-M, Ben Othman, D

Markel, D, Kolodny, Y, Luz, B, Nishri, A

Michel, C

Muller-Sigmund, H D
The use of ${ }^{137} \mathrm{Cs}$ and ${ }^{210} \mathrm{~Pb}$ to model erosive processes in high altitude settings; The Muttsee (Switzerland) example

Diagenetic mineral formation in sediments of the Mississippi River delta plain

Mathematical models of diagenetic processes in marine sediments: iron and manganese redox cycling and nonsteady state diagenesis

Why diagenetic carbonate concretions form: localised microbial buffering

Geochemical studies of salt marsh sediments: Evidence for possible ${ }^{210} \mathrm{~Pb}$ mobility

Developing and applying new techniques for measuring steep chemical gradients of trace metals and inorganic ions at the sediment-water interface

Cycling of iron and manganese in a Riparian wetland

Replacement mechanisms among iron sulphide minerals

Carbonates associated with the Almazan sepiolite-palygorskite deposits (northern Spain)

A new method for the determination of the platinum group elements in sedimentary materials

Hydrogeochemistry of sulphur isotopes in the Kalix River catchment, northern Sweden

High resolution sampling of pore waters using a gel probe from Eshwaite Water, Lake District

Thermodynamics of aqueous $\mathrm{H}_{2} \mathrm{~S}$ solutions at elevated temperatures: solubility and first dissociation constant

Trace $\mathrm{Pb}, \mathrm{Zn}, \mathrm{Cd}, \mathrm{Tl}$ contents and $\mathrm{Pb}-\mathrm{Sr}$ radiogenic isotopes in the dissolved and particulate phases of a river during high-water stage: constraints on the origin(s) and transport of the metals

Tracing phosphorus sources and P-cycling by oxygen isotopes in phosphate; Laker Kinneret (Israel)

A regular pattern of chert within Lower Carboniferous limestones at the Benbulben Range, NW-Ireland

Tracing sedimentary textures and source materials in paragneisses from the Bohemian Massif (Germany) 
Novak, M, Wieder, R K

Pierre, C, Taberner, C, Urquiola, M M, Pueyo, J J

Postma, D

Rickard, D

Sackett, W

Schaller, T, Wehrli, B

Sholkovitz, E

Wehrli, B, Dinkel, C, Muller, B
Sulphur diagenesis in freshwater peatlands

Sulphur and oxygen isotopic composition of sulphates in hypersaline environments, as markers of redox depositional versus diagenetic changes

Kinetics of $\mathrm{Fe}(\mathrm{III})$ reduction in a marine sediment

A new sedimentary pyrite formation model

The utility of sediment pyrolysis

Focusing patterns of transition metals in lake sediments indicators for the reconstruction of deep-water mixing in the past?

Fractionation of Rare Earth Elements in rivers and estuaries

Measurements of benthis gradients in deep lakes with ionselective electrodes and video endoscopy

\section{4b. Weathering of geological systems}

\section{Bricker, O P}

Cochran, M F, Berner, R A

Faure, G, Nishiizume, K

Gislason, S R, Arnorsson, S, Armannsson, $\mathrm{H}$

Holland, H D, Kuo, P H, Rye, $\mathrm{R} \mathrm{O}$

Phillips, F M, Bowen, D Q,

Elmore, D

Schwartzman, D

Tranter, M, Brown, G,

Sharp, $M$,

White, A F, Blum, A E

\section{4c. Weathering of minerals}

Akagi, T, Nakai, S, Masuda, A

Brantley, S L, Stillings, L

Cama, J, Ganor, J, Lasaga, A C

Dobrovolsky, E V

Drever, J I, Murphy, K M, Clow, D W

Ganor, J, Lasaga, A C

Levy, D B, Amrhein, C

Made, B J A D, Ben Baccar, M, Fritz, B

Maurice-Johnsson, P A

May, F

Mogollon, J L, Perez, D, Lo Monaco, S, Ganor, J, Lasaga, A C

Mountain, B W, Williams-Jones, A E

Ngwenya, B T, Shimmield, G B, Elphick, S C

Plettinck, S, Chou, L, Wollast, R
Weathering and mass-balance budgets in small catchments

Vegetative enhancement of chemical weathering

Exposure dating of quartz sandstone in the Transantarctic Mountains by cosmogenic ${ }^{10} \mathrm{Be}$ and ${ }^{26} \mathrm{Al}$

Present chemical weathering of basalt in Iceland

$\mathrm{O}_{2}$ and $\mathrm{CO}_{2}$ in the Late Archaean and Early Proterozoic atmosphere

Surface exposure dating of glacial features in Great Britain

Biotic enhancement of weathering redux

Chemical weathering beneath Alpine glaciers: rates and implications for $\mathrm{CO}_{2}$ drawdown

Effects of climate on chemical weathering in watersheds underlain by granitoid rocks

The tetrad effect, a general effect in partitioning of REE between aqua and solid

An integrated model for feldspar dissolution under acid conditions

The kinetics of smectite dissolution

Replacement reactions during weathering: macrokinetic approach

Field weathering rates versus laboratory dissolution rates: An update

The effects of oxalic acid on kaolinite dissolution rate

The coprecipitation of $\mathrm{Mg}$ and $\mathrm{Si}$ with calcium carbonate

Geochemical modeling of diagenetic reactions

Use of AFM in experimental surface geochemistry

Weathering or hydrothermal alteration? - Examples from the Rhenish Massif, Germany

The effect of $\mathrm{pH}, \mathrm{HClO}_{4}, \mathrm{HNO}_{3}$ and delta $\mathrm{Gr}$ on the dissolution rate of natural gibbsite using column experiments

Experimental simulations of fluid-rock interaction: The effect of surface area on the rate of alteration

An experimental study of fluid-rock interaction: application to groundwater aquifers

Kinetics and mechanisms of dissolution of silica at room temperature and pressure 
Pokrovsky, O S

Schweda, P, Kalinowski, B

Vali, H, Sears, S K, Hesse, R, Martin, R F

\section{4d. Diagenesis of rocks}

Bock, B, McLennan, S M, Hanson, G N

Bustillo, M, Bustillo, M A

Caritat de, P, Bloch, J, Hutcheon, I, Longstaffe, F J, Abercrombie, $\mathrm{H} \mathrm{J}$

Gorokhov, I M, Turchenko, T

L, Melnikov, N N

Hallbauer, D K, Barton, E S

Hayashi, K-I, Fujisawa, H, Ohmoto, H, Holland, H D Klammer, D

Lopez-Galindo, A, Oloriz, F, Rodriguez-Tovar, F J

Martinez-Ruiz, F, OrtegaHuertas, M, Palomo, I

McGill, R A R, Fallick, A E, Hall, A J

Merino, E, Wang, Y, Deloule, E

Miller, S, Macdonald, D I M

Murphy, A, Jarvis, I

Ortega-Huertas, M, MartinezRuiz, F, Oddone, M, Palomo, I Pablo-Galan, de, L, ChavezGarcia M L, Dimas, G

Palomo, I, Ortega-Huertas, M, Martinez-Ruiz, F, Nocci, M, Parisi, G

Paquette, J, Vali, H, Mountjoy, E W

Prudencio, M I, Gouveia, M A, Sequeira Braga, M A,

Figueiredo, M O

Shikazono, N

Spears, D A
Kinetics of $\mathrm{CaCO}_{3}$ homogeneous precipitation in seawater

Dissolution rates and alteration of muscovite, phlogopite and biotite at $\mathrm{pH} 1$ to 4 , room temperature

An alternative approach to assess the true nature of 2:1 mixedlayer silicates in diagenetic and weathering environments

Does redistribution of rare earth elements in turbidites of the Appalachian foreland basin compromise provenance information?

REE study in Jurassic radiolarites fromthe subbetic, Betic Cordillera, Spain

A comparison of shale compositions from the Western Canada sedimentary basis and the US Gulf coast: the importance of depositional composition on shale diagenesis

Multi-stage illite evolution in Upper Proterozoic shales: $\mathrm{Rb}-\mathrm{Sr}$, XRD and TEM studies

Crustal evolution in the source region of the Witwatersrand sediments, South Africa - evidence from quartz

Geochemistry of Proterozoic $(\sim 1.9 \mathrm{Ga})$ sedimentary rocks from the Labrador district, Canada

Rock porosity and element distribution in an extremely acid sulphate altered Tertiary Latite, Styria, Austria: a comparison

Geochemical traces and sequence stratigraphy analysis during the Upper Jurassic in South Iberia

The Cretaceous-Tertiary boundary in the Betic Cordilleras and Basque Cantabrian Basin; a study of the platinum group elements anomalies

Stable isotopic constraints on palaeoenvironment, temperatures and fluids, from silica and carbonate phases; East Kirkton, West Lothian, Scotland

Genesis of banded, fibrous and twisted quartz by 'catalysis', unstable crystallization fronts, and substitution: selforganisation in agates

Diagenetic and thermal history of a fore-arc basin sequence The Himalia Ridge Formation, Alexander Island, Antarctica

Fluid-rock interactions in chalk groundwater systems: an initial investigation into geochemical composition of Upper Cretaceous chalks from SE England

REE behaviour across the Cretaceous-Tertiary boundary

Diagenesis of Miocene vitric tuffs to zeolites, Mexican Highlands, Mexico

Geochemical characteristics of Toarcian sedimentation in Alpine geological domains

Growth and dissolution characteristics of dolomite studied in ultrathin section: a new TEM approach

$\mathrm{REE}$ distribution as an indicator of the origin of carbonates and silicates in basaltic rocks

Stable isotopes, minor elements and diagenetic alteration associated with Tono sandstone-type uranium deposits in Japan

Geochemistry and mineralogy of some British coals 
Vinogradov, V I

Isotopic indicators of epigenetic alteration of Upper Proterozoic sediments on Siberian platform

4e. Experimental studies of mineral dissolution, interfaces and hydrothermal solutions

See section $2 d$

\section{Groundwater chemistry and palaeohydrology}

Appelo, C A G

Aquilina, L, Boulegue, J F, Sureau, J F

Cardenal, J, Walraevens, $\mathrm{K}$

Caritat de, $\mathrm{P}$

Cave, M, Reeder, S, Metcalfe, R

Dearlove, J P L

Fritz, S J, Harvey, F E, Drimmie, R J, Johnston, C, Frape, $\mathrm{S} \mathrm{K}$

Gascoyne, M

Lesniak, P M

Livnat, A, Spiro, B, Kronfeld, J

Maiwald, U, Pekdeger, A

Metcalfe, R, Darling, W G, Crawford, M B, Hooker, P J, Bath, A H

Michard, G, Pearson, F J Jr.

Okrugin, V M, Kokarev, S G, Okrugina, A M, Chubarov, V $\mathrm{N}$, Shuvalov, R A

Okrugin, V M, Stepanov, I I, Shuvalov, R A

Pauwels, $\mathrm{H}$

Peterman, Z E, Stuckless, J S

Petit, J-C

Pitkanen, P, Snellman, M V

Quattrocchi, F, Calcara, M

Ruotsalainen, P H, Snellman, M V
A chromatographic model for water quality variations in the Aquia aquifer (Maryland, USA)

Hydrogeochemical investigation of the passive margin of the south east basin of France. GPF Programme

Chromatographic pattern in a freshening aquifer (Tertiary LedoPaniselian aquifer, Flanders-Belgium)

Time-dependent variations in groundwater chemistry: the Norwegian groundwater monitoring network

Chemical characterisation of core pore-waters for deep borehole investigations at Sellafield, Cumbria

Baseline hydrogeochemical study of shallow groundwaters in $\mathrm{N}$ E England

Tritium variability of repeated samplings of well waters in south Ontario

Isotopic and geochemical evidence for old groundwaters in a granite on the Canadian shield

${ }^{13} \mathrm{C}$ in low temperature, $\mathrm{CO}_{2}$-charged waters: a need for consistency with carbonate chemistry

Isotopic evidence for age of intense spring activity in the Arava Valley, Israel, during Quaternary times

The influence of open-cast lignite mining on adjacent ground water systems

The origins of deep groundwaters in Cumbria, northwest England: hydrochemical constraints

Chemical evolution of waters in long term interaction with granitic rocks: example of waters from Nagra boreholes, North Switzerland

An unusual example of the interaction of modern hydrothermal system with $\mathrm{Au}-\mathrm{Ag}$ veins (South Kamchatka)

Mercury as pathfinder in geochemical exploration of hydrothermal gold-silver deposits in Kamchatka

Natural denitrification in groundwater in the presence of pyrite: Preliminary results obtained at Naizin (Brittany, France)

Strontium isotope characterization of flow systems in southern Nevada, USA

Applying $\mathrm{MeV}$ ion beam techniques to geochemical issues: Cross-fertilizing nuclear physics and geosciences

Modelling of hydrochemical evolution in coastal regression area in Finland: a mass balance approach

Groundwater chemistry in some Italian seismic areas: space and time correlations with tectonic features and seismic activity

The hydrogeochemical characterization of deep groundwaters in crystalline bedrock: investigations in boreholes with multipackers 
Sanjuan, B, Mossmann, J R, Merceron, T

Stepanov, I I

Varsanyi, I, Kovaks, L O,

Wallin, B G K, Peterman, Z E

Walraevens, K, Cardenal, J
Modelling boom clay formation porewater chemistry: Ion exchange versus dissolution precipitation mechanisms

Distribution of mercury concentrations in the atmosphere over the Western part of the Pacific Ocean

The origin of nitrogen in aquifer systems in the great plain, Hungary

Stable and radiogenic isotope systematics in ground water and fracture fillings at Aspo, Sweden

Aquifer recharge and exchangeable cations in a Tertiary clay layer (Bartonian clay, Flanders-Belgium)

\section{Waste containment and pollutant transport}

Albrecht, A, Beer, J, Gloor, M, Fischer, A, Mattle, N

Atkins, M, Glasser, F P

Ben Othman, D, Luck, J-M

Berry, J A, Bishop, H E, Cowper, M M, Fozard, P R, McMillan, J W, Mountfort, S A

Birke, M, Rauch, U

Chudaeva, V A

Cidu, R, Caboi, R, Fanfani, L, Frau, F

Cooper, G I, Cox, G A, Perutz, $\mathrm{R} \mathrm{N}$

Falck, W E, Biehler, D

Gouveia, M A, Freitas, M C, Prudencio, M I

Guiterrez-Mas, J M, LopezGalindo, A

Jostons, A, Kesson, S E

Le Foresticr, L, Libourel, G, Brown, W L, Mosnier, F, Renaud, $P$

Lee, S, Spears, D A

Lottermoser, B G

Made, B J A D, Jamet, P, Salignac, A

Okrugin, V M, Stefanov, J M, Shuvalov, R A, Okrugina, A M, Stepanov, I I

Ragnarsdottir, K V, Gislason, S $\mathrm{R}$, Thorvaldsson, $\mathrm{T}$, Kemp, A J, Andresdottir, A

Read, D

Rodriguez-Navarro, C, Sebastian, E

Sigg, L, Nowack, B, Xue, $\mathrm{H}$
Aquatic transport behaviour of Cobalt deduced from nuclear reactor derived ${ }^{60} \mathrm{Co}$

Modelling the geochemical degradation of cements in a waste repository

Heavy metals and lead isotopes in mollusks from a coastal pont (Thau, South France) and adjacent Mediterranean Sea

The application of nuclear microprobe analysis and secondary ion mass spectrometry to radioactive waste disposal studies

Geochemical investigations in the urban areas of Berlin

Metal contamination of surface waters of Primorye

Hydrogeochemistry around an epithermal system hosting gold mineralisation

An assessment of experimental glass corrosion by comparison with ancient analogues

The geochemical development of mine waters in the former Uranium - mine Konigstein, Saxony, Germany

Trace elements in the neighbourhood of a coal-fired power station

Heavy metals content in sediments of the continental shelf of Cadiz (SW of Spain)

The Synroc strategy of HLW management

Chemistry and mineralogy of fly ash and filter cakes from the incineration of municipal solid wastes

Potential groundwater contamination from pulverised fuel ash (PFA)

Alteration of noble metal geochemical cycles due to sewage disposal

Modeling of hydro-geochemical processes in waste disposal systems

On ecological-geochemical monitoring in Kamchatka (The Mutnovsky-Asachinsky ore region)

Ejection of trace metals from volcanoes

Geochemistry and radioactive waste management - issues and conflicts

Pollution-derived heavy-metal enrichment on building stones

Role of strong ligands for the infiltration of trace metals into groundwater 
Starostin, V I, Sobolev, R N, Volkov, A B

Sterpenich, J, Le Forestier, L, Libourel, G, Chaussidon, $M$, Barbey, $P$

Szikszay, M, Alexandre, G A L, Toledo, M C M, Hypolito, R, Shimizu, D

Taubald, H, Satir, M

West, J M, Milodowski, A E, Hooker, P J
Forecast of changing migration condition of harmful solutions (on base of study of geological structures development)

Medieval stained glass: a model for leaching of vitrified wastes

Study of mobility of $\mathrm{Zn}, \mathrm{Co}, \mathrm{Cu}$ and $\mathrm{Pb}$ the unsaturated zone in tropical climate

Carbonates in mineral clay liners: a risk for long-term security of waste disposal sites? Experimental, geochemical, and isotopic constraints

The effect of microbial activity on the near and far fields of a Swiss low/intermediate level waste repository

\section{Ocean composition and fluxes during the Quaternary.}

Altabet, M A, Francois, R, Murray, D W, Prell, W

Austin, W E N, Kroon, D, Shimmield, G B, Derrick, S

Beveridge, N, Bertram, C, Elderfield, H, Shackleton, N

Clemens, S C, Gromet, L P, Farrell, J W

Farrell, J W, Pedersen, T F,

Francois, R, Altabet, M A, Yu, E F, Bacon, M P, Labeyrie, L D

Ganeshram, R, Pedersen, T F, Calvert, S E, Murray, J W

Green, D, Jarvis, I, Jarvis, K, Thompson, $\mathbf{J}$

Henderson, G M, Martel, D J, O'Nions, R K, Shackleton, N J

Henderson, G M, O’Nions, R K Lea, D W

Muzuka, A N N

Muzuka, A N N

O'Sullivan, G, Wakefield, S, Cramp, A

Rosenthal, Y, Lam, P, Boyle, E A

Schneider, R R, Muller, P J, Wefer, G

Thomson, J, Higgs, N C, Wilson, T R S, Croudace, I W

Thomson, J, Higgs, N C, Clayton, $\mathrm{T}$
Orbital period variations in ${ }^{15} \mathrm{~N} /{ }^{14} \mathrm{~N}$ ratio in the Arabian Sea: an indicator of past changes in denitrification

High resolution marine records of the last glacial/interglacial transition

$\delta^{13} \mathrm{C}-\mathrm{PO}_{4}$ relationships in the glacial Atlantic

The 100,000 year cyclicity in seawater ${ }^{87} \mathrm{Sr} /{ }^{86} \mathrm{Sr}$; an enviroanalytical artifact?

Sedimentary $\delta^{15} \mathrm{~N}$ patterns in the eastern equatorial Pacific Ocean

Preliminary evidence for a decrease in vertical mixing in the upper water column of the southern ocean during the last glacial maximum

Late-Quaternary history of denitrification in the eastern tropical North Pacific

A study of precious metal concentrations in oceanic sediments

High precision ${ }^{87} \mathrm{Sr} /{ }^{86} \mathrm{Sr}$ measurements on foraminifera from the equatorial Pacific and Indian oceans: The search for climate related seawater ${ }^{87} \mathrm{Sr} /{ }^{86} \mathrm{Sr}$ cycles

${ }^{234} \mathrm{U} /{ }^{238} \mathrm{U}$ ratios in Quaternary planktonic foraminifera

The composition of glacial Antarctic circumpolar deep water and its role in driving changes in atmospheric carbon dioxide

Episodes of ice rafted debris and their effects on primary productivity in the Labrador Sea for the past 31,000 years

Stable isotopic compositions of surficial organic matter along a transect across the Labrador Sea

Inorganic geochemistry of organic-rich sediments: paleoceanographic evidence from the Eastern Mediterranean and Sea of Japan

Precipitation and post-depositional mobility of cadmium in reducing sediments: implications for the Cd oceanic budget

Response of South Atlantic Surface Circulation to African Monsoon Variability: Evidence from Late Quaternary records of geochemical tracers for sea-surface temperatures and productivity

Geochemical evidence of the post-depositional oxidation of the most recent E Mediterranean sapropel

Geochemical signals of diagenesis and Heinrich layers in NE Atlantic sediments of the last glacial period 
Tudhope, S, Chilcott, C, Fallick, A E, Jebb, M, Shimmield, G
Southern oscillation-related variations in rainfall recorded in the stable oxygen isotopic composition of living \& fossil massive corals in Papua New Guinea

\section{Ocean palaeochemistry and the evolution of the ocean basins}

Abouchami, W, Goldstein, S L

Ayora, C, Taberner, C, Pierre, C, Pueyo, J J

Bau, M, Dulski, P

Boyle, E A

Bruckschen, P, Bruhn, F, Veizer, J

Burton, K W, O'Nions, R K, Martel, D J

Cerling, T E

Dubinin, A V, Sval'nov, V N, Shirshov, P P

Emmanuel, L, Renard, M, Rohrlich, V

Fagel, N, Andre, L, Debrabant, $\mathrm{P}$

Hattori, K

Jacobsen, S B

Krupp, R E, Oberthur, T, Hirdes, W

Martinez-Ruiz, F, Bernasconi, $\mathrm{S}$, McKenzie, $\mathrm{J} \wedge$

Melezhik, V A, Fallick, A E

Paytan, A, Kastner, M

Peucker-Ehrenbrink, B, Ravizza, G, Hofmann, A W

Podlaha, O G, Chalimourda, A, Veizer, $\mathbf{J}$

Strauss, $\mathrm{H}$

Zverev, V P
$\mathrm{Pb}$ isotopes in circum-Antarctic $\mathrm{Mn}$ nodules: a tracer of oceanic circulation?

Refining the $\delta^{34} \mathrm{~S}$ and $\delta^{18} \mathrm{O}$ values of sulphate in ancient oceans

Evolution of the yttrium-holmium systematics of seawater through time

Isotopic and elemental tracers in calcium carbonate fossils

$\mathrm{C}-, \mathrm{O}-$ and $\mathrm{Sr}$-isotope stratigraphy of the Lower Carboniferous: High frequency fluctuations as a record of climatic changes?

The influence of erosion and palaeogeography on seawater neodymium during the past 20 million years

Global change in the Late Miocene: terrestrial effects on the ocean carbon isotopic record

REE geochemistry in nodule formation processes in surface sediments of Guatemala Deep, Pacific Ocean

Cyclicity of carbonate geochemistry in lower Cretaceous pelagic limestones of the Vocontian trough (SE France)

Geochemical tools useful in order to discriminate the distinct sedimentary components of deep-sea clays (Neogene Equatorial Indian Ocean).

Cratonization, a cause for the rise of atmospheric oxygen and ocean sulphate in Early Proterozoic time.

The globally integrated view of Earth systems evolution from seawater isotope records: How does it work?

Composition of the early Precambrian atmosphere and hydrosphere: thermodynamic constraints from mineral deposits

Paleoceanographic changes across the Cretaceous-Tertiary boundary: carbon and nitrogen isotope stratigraphy at the Agost section, Spain

A world-wide $2.2-2.0$ Ga-old positive ${ }^{13} \mathrm{C}_{\text {carb }}$ anomaly as a phenomenon in relation to the Earth's major palaeoenvironmental changes

Paleocirculation reconstruction by neodymium isotopic ratios of marine barite

Cosmic dust: Terrestrial accretion rate and solubility in seawater

Determinism in strontium isotope record of seawater

The Neoproterozoic sedimentary sulphur cycle: evidence from the isotopic composition of marine evaporites and sedimentary pyrite

Quantitative estimation of massflows of subsurface waters in the Earth's crust and hydrogeochemical balance of the Earth surface 


\section{Modern submarine hydrothermal processes}

Aggarwal, J K, Palmer, M R, Ragnarsdottir, K V

Andersson, E, Holm, N G

Arnorsson, S, Gislason, S R

Berndt, M E, Seal, R R, Shanks, W C, Seyfried, W E

Beynon, J, Bickle, M J, Chapman, $\mathrm{H} \mathbf{J}$

Bickle, M J, Alt, J C, Teagle, D A H

Bortnikov, N S, Vikentyev, I V, Chernyshov, I V, Agapova, A A

Dia, A N, Aquilina, L, Boulegue, J

Ding, K, Seyfried, W E

Fruh-Green, G L, Bernasconi, S, Buatier, M, Karpoff, A-M, McKenzie, J A

Giese, U, Bau, M,

Holm, N G,

Humphris, S E, Tivey, M K, Thompson, G, Hannington, $\mathrm{M}$ D, Rona, P A

Okrugin, V M, Okrugina, A M, Polushin, S V, Chuvarov, V N

Rickard, D, Knott, R, Duckworth, R, Murton, B

Sakai, H, Kanayama, S, Tsunogai, U, Ishibashi, J, Wakita, $\mathrm{H}$

Strekopytov, S V, Dubinin, A V, Shirshov, P P
Rare earth elements in Icelandic hydrothermal fluids

An experimental approach for studying the stability of organic compounds under simulated submarine hydrothermal conditions.

$\mathrm{CO}_{2}$ from magmatic sources in Iceland

$\mathrm{D} / \mathrm{H}$ fractionation during phase separation of seawater in subseafloor hydrothermal systems : Isobaric heating and adiabatic decompression.

A strontium isotopic investigation of fluid-solid exchange during hydrothermal circulation in the Troodos ophiolite

Sulphur transport and sulphur isotope fractionations in ocean floor hydrothermal systems

Lead isotope systematics in sulphides from modern hydrothermal vents: a comparison of mid-ocean and backarc settings (Pacific)

Geochemical evidence of continental fluid circulation in the Peru subduction zone

Effect of conductive cooling on chemistry of mid-ocean ridge hydrothermal fluids: experimental and theoretical constraints

Reaction control of the chemical and isotopic compositions of hydrothermal fluids at a sedimented ridge (Middle Valley, ODP Leg 139)

Trace element accessibility in mid-ocean ridge and ocean island basalt: An experimental approach

Hydrothermal activity and the volume of the oceans

Investigating the formation of the active TAG hydrothermal mound using observational, petrographic and geochemical data

Sulphides of contemporary land and submarine hydrothermal systems of Kamchatka

Organ pipes, beehive diffusers and chimneys at the Broken Spur hydrothermal sulphide deposits, $29^{\circ} \mathrm{N}$ MAR

Gas geochemistry of submarine hydrothermal systems at Okinawa Trough Backarc Basin and Ogasawara Arc

Rare earth elements, zirconium and hafnium geochemistry in processes of sedimentation and nodule formation in the North-East Pacific

\section{Mechanisms of isotopic and chemical communication in crust and mantle rocks}

10a. Small-scale evidence of geochemical processes in mantle rocks and ultrabasic complexes See section $14 g$

10b. Spatial distribution of isotope and trace element variations in rocks and magmas, and their implications

Abart, R

Boyce, A J, Fallick, A E, Fletcher, T J, Russell, M J, Ashton, J H
Isotopic disequilibrium during metasomatic vein formation

Detailed sulphur isotope studies of Lower Palaeozoic-hosted pyrite below the giant $\mathrm{Navan} \mathrm{Zn}+\mathrm{Pb}$ mine, Ireland: evidence of mass transport of crustal $\mathrm{S}$ to a sediment-hosted deposit 
Bruhn, F, Bruckschen, $\mathrm{P}$, Veizer, $\mathbf{J}$

Burch, T E, Cole, D R

Farquhar, J, Chacko, T, Ellis, D J

Gregory, R T, Gray, D R

Hallbauer, D K

Halliday, A N, Lee, D-C, Christensen, J N, Yi, W, Hall, C M, Jones, C E, Teagle, D, Walder, A J, Freedman, P A

Hammouda, T, Pichavant, M, Chaussidon, $M$

Hinton, R W, Paterson, B A

Kelley, S P, Carroll, M R, Brooker, R A, Draper, D S

Lyon, I C, Saxton, J M, Burley, S D, Guscott, S, McKeever, P J, Turner, $\mathrm{G}$

McCandless, T E, Ruiz, J, Adair, B I

McKibben, M A, Eldridge, C S

Parsons, I, Lee, M R, Waldron, K A, Walker, F D L, Burgess, R, Brown, W L

Riciputi, L R, Paterson, B A

Rogan, W, Blake, S

Smith, M, Yardley, B W D

Tepley, F J, Davidson, J P, Holden, $\mathrm{P}$

Valley, J W, Eiler, J M, Kohn, M J, Spicuzza, M J,

Baumgartner, L P,

Elsenheimer, D, Graham, C M

Wada, $\mathrm{H}$, Ando, $\mathrm{T}$

Wiechert, U, Hoefs, J
Isotopic composition and diagenetic alteration of Lower Carboniferous brachiopod shells: constraints from proton microprobe (PIXE) trace element analysis

Stable isotope exchange kinetics in the system calcite $\pm \mathrm{CO}_{2} \pm$ $\mathrm{H}_{2} \mathrm{O}$ to $700^{\circ} \mathrm{C}, 1000$ bar: the effect of fluid composition

High-temperature oxygen isotope thermometry in two contrasting terranes, the Taltson Magmatic Zone, Canada and the Napier Complex, Antarctica

Oxygen isotopic composition of veins and host rocks as tracers of fluid rock interaction in the crust

Geochemical trace element analysis for ionic species by capillary electrophoresis

I.C.P. magnetic sector multicollector mass spectrometry and its applications to geochemistry

Mechanisms of isotopic equilibration during partial melting: an experimental test of the behaviour of $\mathrm{Sr}$

Crystallisation history of granitic magma: evidence from trace element zoning

Measurement of laboratory produced argon diffusion and solubility in glasses and minerals using UV laser ablation microprobe

High spatial resolution measurements of $\delta^{18} \mathrm{O}$ in authigenic quartz overgrowths

Platinum group mineralization in the Bushveld Complex: a combined QEM-SEM and LA-ICPMS study

Micron-scale isotopic zoning in minerals : a record of large scale geologic processes

Role of microtexture in isotopic exchange and weathering in alkali feldspars

In-situ analysis of oxygen isotope ratios in silicates and carbonates by ion microprobe

Trace element zonation of phenocrysts from Ngauruhoe Volcano, New Zealand: constraints on magmatic processes

The boron isotopic composition of tourmaline as a guide to fluid processes and boron source in the SW England orefield: an ion microprobe study

Isotopic monitoring of magma mingling at Chaos Crags, Lassen Volcanic Park

Contrasting styles of oxygen isotope exchange

The role of the grain boundary at chemical and isotopic fronts in marble during contact metamorphism: microscale isotopic zoning in calcite

First results with a UV laser based microanalytical preparation technique for an in situ determination of oxygen isotope ratios of silicates $\&$ oxides 


\section{Partitioning of elements}

\section{1a. Partition coefficients for silicate melts, minerals and associated fluids}

Barclay, J, Carrol, M R

Beattie, $P$

Blundy, J D, Wood, B J

Brenan, J M, Shaw, H F, Phinney, D L

Dalpe, C, Baker, D R

Foley, S F, Jenner, G A, Jackson, S E, Fryer, B J

Harte, B, Kirkley, M B

Horn, I, Foley, S F, Jackson, S E, Jenner, G A

\section{Johnson, K T M}

Klein, M, Seck, $\mathrm{H}$ A, Stosch, $\mathrm{H}$ G, Shimizu, N

Kravchuk, I F

Libourel, G, Deloule, E, Toplis, M J

Nielsen, R L, Forsythe, L M, Hack, P J, Gallahan W E, Fisk, M R, Johnston, A D

Peters, M T, Shaffer, E E, Burnett, D S

Ryabchikov, I D

Sweeney, R, Prozesky, V, Przybylowicz, W

Urusov, V S
Volatile and trace element partitioning for a peralkaline rhyolite volcano

What determines the values of mineral/melt partition coefficients?

Energetics of element partitioning between minerals and melts

Experimental determination of trace element partitioning between pargasitic amphibole and hydrous silicate melt

Partition coefficients for rare-earth elements between calcic amphibole and Ti-rich basanitic glass at $1.5 \mathrm{Gpa}, 1100^{\circ} \mathrm{C}$

Trace element partition coefficients between phlogopite, clinopyroxene and matrix in an alkaline lamprophyre from Newfoundland, Canada

Variations in $\mathrm{REE}, \mathrm{Y}$ and $\mathrm{Zr}$ partitioning between clinopyroxene and garnet as a function of major element composition

Compositional dependencies of the partition coefficients for $\mathrm{Zr}$, $\mathrm{Nb}, \mathrm{Ta}, \mathrm{Hf}$ and selected transition elements between spinel and melt

Experimental $\operatorname{cpx} /$ and garnet/melt partitioning of REE and other trace elements at high pressures

Experimental REE partitioning between amphibole, clinopyroxene, garnet and basaltic to tonalitic melts:

Experimental study of elements partitioning in equilibria meltfluid at high pressure

Phosphorus partitioning in basalts: an experimental and ion probe study

The compositional dependence of HFSE partitioning: a comparison between Pyroxene- and Magnetite-melt systematics.

Temperature and time marking of crystal growth during crystalliquid partitioning experiments: $\mathrm{A}$ new technique and applications to anorthite-liquid

Experimental data on major and trace element partitioning in partially molten carbonated peridotites

Trace element partitioning between silicate minerals and carbonatite and silicate melts at $18 \mathrm{~kb}$ to $46 \mathrm{~kb}$ pressure

Theoretical estimations of equilibrium partitioning of elements between crystals and binary melts (fluids)

\section{1b. Partitioning of sulphide phases and precious metals}

Barnes, S-J, Makovicky, E, Karup-Moller, S, Makovicky, M, Rose-Hansen, J

Capobianco, C J, Drake, M J

Dobrovolskaya, M G, Basalaeva, I V, Vikentyev, I V

Fleet, M E, Crocket, J H, Stone, W E

Fleet, M E, Wu, T-W

Shcherbakov, Y G
Partition coefficients for $\mathrm{Ni}, \mathrm{Cu}, \mathrm{Pd}, \mathrm{Pt}, \mathrm{Rh}$ and $\mathrm{Ir}$ between monosulphide solid solution and sulphide liquid and the implications for the formation of compositionally zoned $\mathrm{Ni}$ $\mathrm{Cu}$ sulphide bodies by fractional crystallization of sulphide liquid

Partitioning and solubility of PGEs in oxides and silicates

Precious metals ( $\mathrm{Pt}, \mathrm{Pd}, \mathrm{Au}, \mathrm{Ag}$ ) in copper-pyritic deposits of the South Urals

Sulphide liquid/silicate melt partition coefficients for platinumgroup elements and gold

Experiments on the volatile transport of precious metals at $1000^{\circ} \mathrm{C}$

Geochemical properties of natural systems 
Shengrong, L, Zhenmin, G

Sobolev, R N

van Moort, J C
Some typical partition and distribution patterns of platinum group elements

Gold behavior in the process of the acid magma crystallization

The chemical composition and paramagnetism of auriferous quartz

\section{Dehydration, partial melting and fluid distribution in the crust}

Barnicoat, A C, Cartwright, I,

Benner, E, Hoernes, S,

Bickle, M J, Chapman, H J, Fallick, A, Ferry, J M, Rumble, D

Brandon, A D, Creaser, R A, Chacko, $\mathrm{T}$

Braun, I, Raith, M

Brown, M

Buick, I S, Cartwright

Cameron, E M, Hattori, $\mathrm{K}$

Carrington, D P, Watt, G R

Cartwright, I, Vry, J K, Sandiford, M J

Chacko, T, Creaser, R A, Poon, D

Cole, C, Graham, C,

Delgado, J, Venemann, T, O'Neil, J R

Dunai, $\mathbf{T} \mathbf{J}$

Fitzsimons, I C W

Forster, H-J, Tischendorf, G

Harley, S L

Harris, N, Ayres, M, Massey, J Heming, $G$

Hensen, B J, Osanai, Y

Holness, M, Fallick, A E

Huizenga, J M, Touret, J L R

Kotkova, J
Focused fluid flow during subduction

Stable isotope systematics in metasediments of the Scottish Highlands

Oxygen, carbon and strontium isotopic constraints on fluid movement during the Acadian metamorphism in southcentral Maine

Rapid ascent of granitoid magmas from the lower crust

The leptynitic gneisses of the Kerala Khondalite Belt, southern India: phenomena and mechanism of dehydration/melting at granulite facies conditions

Melt segregation mechanism controls on the geochemistry of crustal melts

Fluid-rock interaction across a greenschist-to granulite-facies transition, Reynolds Range, central Australia

Highly oxidized deep metamorphic zones: occurrence and origin

Contrasting geochemistry of granulite-facies leucosomes and Stype granites: K-feldspar as culprit

Changes in oxygen isotope ratios of metasediments during regional-metamorphic crustal-scale fluid flow, Mount Lofty Ranges, South Australia

Spinel + quartz granites and associated metasedimentary enclaves from the Taltson Magmatic Zone, Alberta, Canada

Stable isotope and textural evidence on the mechanisms of metamorphic fluid infiltration within a zone of structurally focused high fluid flux

The origin of metasomatic fluids in skarns from La Maladeta (Central Pyrenees, Spain): $\mathrm{C}, \mathrm{O}, \mathrm{H}, \mathrm{S}$ and $\mathrm{Sr}$ isotope compositions

Mantle-derived $\mathrm{CO}_{2}$ and granulite genesis: evidence from noble gases

Cordierite migmatites from East Antarctica - geochemical constraints on volatile distribution during crustal anatexis

Evolution of the Hercynian granite magmatism in the Erzgebirge metallogenic province

Cordierite as a sensor of fluid and melt distribution in crustal metamorphism

Chemical disequilibrium during crustal anatexis

The tectonogeochemical dynamic system in dexing porphyry copper deposit, Southeast of China

Experimental study of dehydration melting of F-bearing biotite in model pelitic compositions

Palaeohydrology of the Beinn an Dubhaich aureole, Skye, and inferred mechanisms of fluid infiltration in carbonates

Fluid inclusion compositions as a geo-thermobarometer: Example of the Umwindsi shear zone, NE Zimbabwe

Are North Bohemian felsic granulites products of HT-HP melting? 
Lewis, A J, Palmer, M R, Kemp, A J

Massey, J

Metcalfe, R, Bevins, R E, Robinson, D

Moller, A, Mezger, K, Schenk, V

Mozgova, N N, Borodaev, Y S, Gandhi, S M

Nabelek, P I

Patino-Douce, A E

Pattison, D R M, Begin, N J

Philippot, $\mathrm{P}$

Poitrasson, F, Montel, J-M, Duthou, J-L, Pin, C, Chenery, $\mathrm{S}$

Putlitz, B, Schliestedt, M, Matthews, A

Skelton, A D L

Spear, F

Touret, J L R

Treloar, P J, Wheeler, J, Potts, G J

Vielzeuf, D, Montel, J M

Waters, D J

Wickham, S M

Wilson, M R, Dunning, G R, Cawood, P A

Yardley, B W D, Banks, D A Yaxley, G M, Green, D H, Klapova, $\mathrm{H}$
Variations of the rare earth element abundances in hydrothermal waters from the Yellowstone hydrothermal system, Wyoming, USA

Contrasting fluid-deformation-melt histories within the high Himalayan crystallines, Langtang Valley, Nepal

Theoretical constraints on calcium silicate domain formation and fluid flow during alteration of basic igneous rocks

Reconstruction of crustal genesis in a high-grade gneiss terrane using $\mathrm{Sm} / \mathrm{Nd}$-whole rock systematics and $\mathrm{Pb}$-isotopes of leached feldspar

Partial melting features of metamorphosed ores from Rangpo polymetallic deposit (Sikkim, India)

Dehyrdration melting and differential uplift of a partially molten crust in the Black Hills, South Dakota, USA

Melt generation in the continental crust: answered and unanswered questions

Hierarchy of closure temperatures in granulites and the importance of an intergranular exchange medium (melt?) in controlling maximum $\mathrm{Fe}-\mathrm{Mg}$ exchange

Fluid and halogen activities in the high-grade blueshists from the Dora-Maira Massif, Western Alps

Hydrothermal remobilisation of $\mathrm{Sm}-\mathrm{Nd}$ isotopes at the mineral scale in granites

Fluid and geochemical constraints on the formation and retrogression of high-pressure metamorphic rocks from Sifnos (Greece)

Fluid flow in Vermont \& New Hampshire, USA: A 3-D perspective

P-T-t evolution of the Valhalla complex, British Columbia, Canada

Fluid-absent and fluid-dominated domains in granulites and eclogites

Metamorphism and melting within the Nanga Parbat syntaxis, Pakistan Himalaya

Experimental constraints on partial melting in the crust

Textural studies of migmatitic granulites: solid-melt reactions and the role of fluids

Batholithic K-rich silicic magmatism in east-central Asia: evidence for a mantle source for progressive regional crustal potassium enrichment.

Fluid compositions in crustal-scale plumbing systems related to contrasting styles of Ordovician and Silurian orogenesis, Northern Appalachians, Newfoundland

The ligand chemistry of crustal fluids

The refractory nature of carbonate during partial melting of eclogite: evidence from high pressure experiments and natural carbonate-bearing eclogites

\section{Magma generation processes}

\section{3a. Experimental constraints on melting in the mantle}

Baker, M B, Stolper, E M
The composition of high-pressure mantle melts: results from diamond aggregate experiments 
Danyushevsky, L V, Green, D H, Falloon, T J, Sobolev, A V

Gaetani, G A, Grove, T L

Green, D H

Kinzler, R J

Kushiro, I

Rapp, R P

Robinson, J A C, Wood, B J

Soulard, H, Wood, B J
The compositions of anhydrous and $\mathrm{H}_{2} \mathrm{O}$-undersaturated melts in equilibrium with refractory peridotites at 15 and $20 \mathrm{~kb}$ : Implications for high-Ca boninite petrogenesis

Melting in the sub-arc mantle: the effects of $\mathrm{H}_{2} \mathrm{O}$ on primary magmas and the spinel-to-garnet transition

Experimental definition of mantle melting and implications for mantle dynamics

Melting of mantle peridotite at pressures approaching the spinel to garnet transition

Melting behaviour of mantle peridotites and compositional variations of partial melts at high pressures

Partial melting of metabasalts at 2-7 GPa

Low degree hydrous and anhydrous partial melting of peridotite

Lherzolite partial melting: closer to primary liquids

\section{3b. Source regions, extraction and evolution of basaltic melts}

Albarede, F, Bachelery, $\mathrm{P}$, Fitton, J G, Joron, J L, Kaminski, E, Luais, B, Semet, M, Upton, B

Andronikov, A V

Aparicio, A, Arana, V, Garcia, R, Grachev, A

Baker, J, Menzies, M, Snee, L, Thirlwall, $\mathrm{M}$

Barling, J

Bell, K

Brake, C R, Fitton, J G

Churikova, T G

Class, C, Goldstein, S L

Cohen, A S, O'Nions, R K

Crawford, A J, Kamenetsky, V S, Lanyon, $R$, Varne, $R$

Ellam, R M, Olive, V, Mitchell, C

Elthon, D

Fitton, J G, Saunders, A D, Harðarson, B S, Shipboard Scientific Party

Furman, T, Graham, D

Garland, F, Turner, S, Hawkesworth, C, Kerstein, L

Goldstein, S J, Perfit, M R, Batiza, R, Fornari, D J, Murrell, M T

Goldstein, S L, Miller, D M, Langmuir, $\mathrm{C} \mathrm{H}$, Hofmann, A W
Time scales and mechaisms of geochemical fluctuations in the Piton de la Fournaise volcano, Réunion Island

Glass in lherzolite inclusions from Jetty Peninsula (East Antarctica)

The origin of the Columbretes Islands, Basanitic and phonolitic magmas (Western Mediterranean)

Stratigraphy, ${ }^{40} \mathrm{Ar} /{ }^{39} \mathrm{Ar}$ geochronology and geochemistry of flood volcanism in Yemen

Origin and evolution of a high-Ti ocean island basalt suite: The Laurens Peninsula Series, Heard Island, Indian Ocean

Carbonatites and mantle evolution: A review

Tholeiitic magmatism in the Belingwe greenstone belt

Modelling of the magmatic process of the PlosKie Sopky volcano

Ocean island basalts and lithospheric melting: constraints from the source mineralogy

Variations in the $\mathrm{Th} / \mathrm{U}$ ratio and $\mathrm{Th}$ isotope compositon of Mauna Loa tholeiites

Macquarie Island: interactions between the Balleny HIMU plume and the southeast Indian ridge: metasomatism of MORB source mantle and contamination of MORB magmas

Compositional variations in the sub-continental lithospheric mantle and implications for its role in basalt petrogenesis

Refertilization in a convecting mantle: effects on primary MORB compositions

Constraints on the nature of the Iceland plume from ODP Leg 152 (south-east Greenland volcanic rifted margin)

Chemical and isotopic variations in volcanic rocks from the Rungwe Province

Major element modelling of changes in lithospheric source with time for the Parana CFB

${ }^{226} \mathrm{Ra}$ and ${ }^{231} \mathrm{~Pb}$ systematics of axial MORB, crustal residence ages, and magma chamber characteristics at $9-10^{\circ} \mathrm{N}$ East Pacific Rise

How large is the mantle source of ocean island basalt? 
Grove, T L, Kinzler, R J, Gaetani, G A

Gurenko, A A, Chaussidon, M

Haase, K, Goldstein, S L, Devey, C W, Stoffers, P

Hanan, B B, Graham, D W, Michael, P J

Harðarson, B S, Fitton, J G

Hart, S R

Hauri, E H, Wagner, T P, Kurz, M D

Hawkesworth, C J, Gallagher, $\mathrm{K}$, Turner, $\mathrm{S}$

Hergt, J M, Storey, M, Marriner, G, Tarney, J

Hirschmann, M, Stolper, E M, Ghiorso, M S

Huang, Y-M, van Calsteren, $\mathrm{P}$, Hawkesworth, C, Black, P, Smith, I

Iwamori, H, McKenzie, D

Kelemen, P B, Shimizu, N, Salters, V J M

Kent, R, McKenzie, D

King, P M, Hawkesworth, C J, Rogers, N W

Langmuir, $\mathrm{C} \mathrm{H}$

McKenzie, D

Meen, J K, Elthon, D

Michael, P J

Mitchell, C, Fitton, J G, Al'mukhamedov, A L, Medvedev, A I

Molzahn, M, Reisberg, L, Worner, $G$

Nielsen, R L, Crum, J, Bourgeois, R, Hascall, K, Forsythe, L, Christie, D M, Fisk, M R

O'Hara, M J

\section{O'Hara, M J}

O'Hara, M J

O'Hara, M J

Oskarsson, N, Grunvold, K, Sigvaldason, G E

Peccerillo, A, Gazaegn. Y, Dereje, A

Rehkamper, M, Hofmann, A W
Using constraints from experimental petrology to model mantle melting processes under anhydrous and hydrous conditions

Coexistence of enriched and depleted primitive melts as inclusions in olivine from Reykjanes tholeiites, Iceland

Magma genesis and mantle sources in the Easter hotspot-Easter Microplate system

Highly correlated lead, strontium, and helium isotopes in MidAtlantic Ridge basalts from a dynamically evolving spreading centre at $31-34^{\circ} \mathrm{S}$

Geochemical variation in the Tertiary basalts of Iceland

Mantle plumes and other mail from the mantle

Melt generation and migration beneath Kilauea: Constraints from Os isotopes and phase equilibria

Causes of melt generation in the sub-continental mantle

The Curaçao lava formation: Samples of the oldest and most primitive magmas from the Galapagos Plume

Perspectives on shallow mantle melting from thermodynamic calculations

OIB-like magmatism in Auckland, New Zealand

Melt segregation and P-T path of mantle melting

Focussed flow of melt in the upper mantle: Extraction of MORB beneath oceanic spreading ridges

Rare earth element inversion models for basalts associted with the Kergelen mantle plume.

Magmatism and extension in the Azores

Major element heterogeneity in the mantle: Constraints from a general model for basalt petrogenesis

Melt movement in the mantle

Ferrodiorites from the Mid-Cayman Rise

Evidence from trace elements and $\mathrm{H}_{2} \mathrm{O}$ from regionally distinctive sources of MORB : Implications for evolution of the depleted mantle

The age and duration of flood basalt magmatism : geochemical and palaeomagnetic constaints from the Siberian province

Isotopic studies $(\mathrm{Sr}, \mathrm{Nd}, \mathrm{Pb}, \mathrm{Os}, \mathrm{O})$ of the Jurassic Ferrar floodbasalt province of Northern Victoria Land, Antarctica

Local diversity of MORB parent magmas: Evidence from melt inclusions in high-An feldspar from the Gorda Ridge

Combining reversed and subdued discrimination with high relative concentrations of incompatible elements

Superimposing magma chamber and melting regime processes: How easy is it to (mis)interpret the liquid products?

Imperfect crystal-liquid separation processes

Integrated melts from melting regimes of different shapes

Composition of basalts above the Iceland mantle plume

Genesis of acid volcanism in continental rift environments : a case in the Ethiopian Rift Valley

Trace element anomalies and correlations in Indian Ocean MORB 
Reid, M R, Ramos, F C

Richardson, C, McKenzie, D

Rogers, N W, Hawkesworth, C J

Salters, V J M, Bourdon, B, Elliot, T E

Shimizu, N

Shirey, S B, Barnes, S-J

Sigmund, J, Keller, J

Sims, K W W

Slater, L, Gronvold, K, Shimizu, N, McKenzie, D Smith, A D

Sobolev, A V, Gurenko, A A, Shimizu, N

Sobolev, A V, Shimizu, N

Stewart, K, Kelley, S, Turner, S, Hawkesworth, C,

Mantovani, $M$

Wall, F, Barreiro, B A, Spiro, B

Widom, E, Hoernle, K, Shirey, $\mathrm{S}$ B, Schmincke, $\mathrm{H}-\mathrm{U}$

Wilson, $\mathbf{M}$, Rosenbaum, $\mathbf{J} \mathbf{M}$, Downes, $\mathrm{H}$

Woodhead, J D
Timescales of magma chamber processes from Th isotope systematics

Radioactive disequilibria from two-dimensional models of melt generation in plumes and ridges

Compositional variations in basalts from the Western Great Basin, California and Nevada, USA

Constraints on the MORB melting regime based on the Lu-Hf and $\mathrm{Sm}-\mathrm{Nd}$ systematics

Depths of melting and melt extraction beneath mid-ocean ridges as recorded in melt inclusions

$\mathrm{Re}-\mathrm{Os}$ and $\mathrm{Sm}-\mathrm{Nd}$ isotopic constraints on basaltic komatiitic volcanism and magmatic sulphide formation in the Cape Smith Foldbelt, Quebec

Amphibole and garnet bearing mantle xenoliths in the Kaiserstuhl, Germany: relation to diatreme and carbonatite

Correlated U-Th and Sm-Nd fractionation in Mid-Ocean Ridge and Ocean Island Basalts: Implications for basalt petrogenesis

Melting beneath the Theistareykir region, NE Iceland

Mississippian Ocean Island Basalts from the western palaeopacific ocean in the Cache Creek terrane of British Columbia.

Ultra-depleted melts from Iceland: data from melt inclusion studies

The origin of typical NMORB: The evidence from melt inclusions study

3-D ${ }^{40} \mathrm{Ar}-{ }^{39} \mathrm{Ar}$ geochronology in the Parana flood basalt province

Isotopic evidence for late-stage processes in carbonatites: rare earth mineralization in carbonatites and quartz rocks at Kangankunde, Malawi

Os isotope systematics in the Canary Islands

Evolution of the European mantle lithosphere, a $\mathrm{Sr}-\mathrm{Nd}-\mathrm{Pb}$ isotope perspective

The geochemistry of Mangaia (Cook Islands) and evaluation of the recycling model for the origin of the HIMU OIB signature

\section{3c. Melt generation at destructive margins}

Falloon, T J, Green, D H, Jacques, A L

Forde, E J, Thirlwall, M F, Vroon, P Z, Hall, $R$

Kamenetsky, V S, Sobolev, A V

Kelemen, P B

Kersting, A, Arculus, R

Kilian, R, Stern, C E

Korkmaz, S, Tuysuz, N, Kurt, $\mathrm{H}$, Arslan, $\mathrm{M}$
Refractory magmas in back-arc basin settings - experimental constraints on a Lau Basin example

Geochemical constraints on source contributions to the Neogene intraoceanic arc volcanism in Halmahera, Eastern Indonesia

Geochemical constraints on genesis of Kamchatka Arc ultramafic melts

Origin of High $\mathrm{Mg \#}$ andesite and the continental crust

$\mathrm{Pb}$ systematics of Klyuchevskoy volcano, Kamchatka and North Pacific sediments:

New trace elements and isotopic constraints on the genesis of andesites and dacites of the Quaternary Austral volcanic zone of the Andes

Geochemistry and evolution of the volcanism in the eastern Pontides, NE-Turkey 
Murphy, M D, Brewer, T S

Pearce, J A, Parkinson, I J, Peate, D W

Turner, S, Hawkesworth, C, Macdonald, R, Black, S, van Calsteren, $\mathrm{P}$

Verma, S P

Vroon, P Z, Lowry, D, Van Bergen, M J
Geochemistry of mafic magmas from Sollipulli Volcano, southern Chile : constraints on models of magma genesis in the Southern Volcanic Zone of the Andes

Geochemical evidence for magma generation above subduction zones

$\mathrm{Th}, \mathrm{Ph}, \mathrm{Nd}$ and $\mathrm{Sr}$ isotope variations in volcanic rocks from the Lesser Antilles

Geochemical and isotopic constraints on the origin of the mafic volcanism in central Mexico

Oxygen- and Sr-isotope systematics of the Banda Arc volcanics (Indonesia): Evidence for subduction of continental material

\section{3d. Mafic-ultramafic rocks and complexes}

See section $14 f$

\section{Mantle development in space and time}

14a. Experimental constraints on melting in the mantle

See section $13 a$

14b. Source regions, extraction and evolution of basaltic melts

See section $13 b$

14c. Mantle mineralogy and the transition zone.

See section $2 c$

\section{4d. Large scale mantle to terrestrial geochemistry}

Blichert-Toft, J, Luais, B

Carmichael, I

Chaussidon, M, Marty, B

Chauvel, C, Goldstein, S L, Hofmann, A W

Clayton, R N, Humayun, $M$

Crozaz, $\mathrm{G}$

Dick, H J B, Natland, J, Leg 147 Scientific Party

Galer, S J G

Galer, S J G, Laue, H-J, Goldstein, S L, Mezger, K, Hofmann, A W

Gilmour, J D, Ash, R D, Turner, $\mathrm{G}$

Harmon, R S, Hoefs, J

Harper, C L, Jacobsen, S B Hawkesworth, C J, Turner, S
The lifetimes of ancient chemical heterogenities in the mantle and their implications for the evolution of mantle convection.

Basic magmas vary by eight orders of magnitude in oxygen fugacity: is this range required for their mantle source region?

Boron isotope variations in OIB and BABB

Surface processes control $\mathrm{Pb}$ evolution in the mantle

Stable isotope evidence for Earth's raw materials

A re-evaluation of the ${ }^{244} \mathrm{Pu}$ chronometer

Melt transport and evolution in the shallow mantle beneath the East Pacific Rise: Preliminary results from ODP Site 895

Revised decay energies of potassium, thorium and uranium, and the thermal history of the Earth

Concept of a new thermal isotope mass spectrometer

Iodine-xenon studies of ordinary chondrites using RELAX

A global analysis of the oxygen isotope composition of basalts: Evidence for low and high ${ }^{18} \mathrm{O}$ reservoirs in the mantle

Extinct radionuclide decay signatures and mantle evolution

The composition of the sub-continental mantle: evidence from magmatic rocks 
Hofmann, A W, Stein, M Jacob, D E, Jagoutz, E, Lowry, D, Mattey, D, Rosenhauer, M, Kudrjavtseva, G P

Jochum, K P, Hofmann, A W

Luais, B

Mattey, D P, Lowry, D, Macpherson, C G, Chazot, G

Menzies, M A

Pearson, D G, Boyd, F R, Hoal, K E O, Hoal, B G, Nixon, $P$ $\mathrm{H}$, Rogers, N W

Pearson, D G, Snyder, G A, Shirey, S B, Taylor, L A, Sobolev, N

Shirey, S B

Wedepohl, K H

14e. Rare gases

Allegre, C J, Staudacher, T Graham, D W

Marty, B, Trull, T, Lussiez, $\mathrm{P}$, Basile, I, Tanguy, J C

Moreira, M, Sarda, P, Allegre, C J, Schilling, J-G

O'Nions, R K

Perez, N M, Wakita, H, Nakai, S, Sano, Y, Williams, S N

Staudacher, T, Moreira, M, Allegre, $\mathrm{C} \mathrm{J}$
Episodic crustal growth and mantle evolution

Diamondiferous eclogites from Udachnaya: a subducted component in the Siberian upper mantle

Antimony in mantle-derived rocks: constraints on Earth evolution from moderately siderophile elements

$\mathrm{Pb}$ isotope evolution of Archaean granitoids: inferences on world-wide mantle heterogeneity and post-emplacement processes

Oxygen isotope composition of mantle minerals by laser fluorination analysis: homogeneity in peridotites, heterogeneity in eclogites

Plate tectonics and lithosphere architecture: Temporal and spatial consequences

A Re-Os isotopic and petrological study of Namibian peridotites: contrasting petrogenesis and composition of onand off-craton lithospheric mantle

$\mathrm{Re}-\mathrm{Os}$ isotope evidence for a mid-Archaean age of dimondiferous eclogite xenoliths from the Udachnaya kimberlite, Siberia:

Evolution of the Earth's mantle: perspective from the Re-Os isotopic system

The composition of the continental crust

Rare gases systematics and mantle structure

Helium isotope variations along mid-ocean ridges : mantle heterogeneity and melt generation effects

Origin and evolution of Mount Etna magmatism: isotope constraints

Noble gas systematic of Shona Seamount, $52^{\circ}$ South Atlantic

Degassing history of the Earth

${ }^{3} \mathrm{He} /{ }^{4} \mathrm{He}$ isotopic ratios in volcanic-hydrothermal discharges from the Canary Islands, Spain: Implications on the origin of the volcanic activity

Heterogeneity and scatter of helium isotopic ratios in MORB

\section{4f. Mantle fluids and mantle metasomatism}

See also listing under $14 g$

Chazot, G, Menzies, M A, Harte, B, Mattey, D

Deines, $\mathrm{P}$

Mathez, E A, Hunter, R H, Kinzler, R J

Minarik, W G, Brenan, J M

Odling, N W A

Riley, T R, Bailey, D K, Lloyd, F E, Fenwick, C S, Palmer, M R
Carbonatite metasomatism and melting of the Arabian lithosphere: Evidence from oxygen isotopes and trace element composition of spinel lherzolites

On the importance of fluids for diamond growth

Crystallization of the Bushveld Complex and its bearing on melt percolation and metasomatism in the mantle

Connectivity of volatile-rich melts in mantle source-regions: Constraints from Fe-transport experiments

Experimental evidence for the nature of upper mantle metasomatism

Carbonate metasomatism in the Eifel (Germany) subcontinental lithosphere: geochemical and isotopic signature 
Schiano, P, Clocchiatti, R, Shimizu, N

Schrauder, M, Navon, O, Szafranek, D, Kaminsky, F V, Galimov, E M

Schrauder, M, Koeberl, C

van der Laan, S R, Foley, S F

Zinngrebe, E, Foley, S
Melt inclusions trapped in mantle minerals: a clue to identifying metasomatic agents in the upper mantle beneath continental and oceanic intraplate regions

Fluids in Yakutian and Indian diamonds

Trace element analyses of fluid-bearing fibrous diamonds from Jwaneng (Botswana) by neutron activation analysis

MARIDs and mantle metasomatism

Metasomatism in two natural peridotites: effects of low- $a \mathrm{SiO}_{2}$ melts

\section{4g. Small-scale evidence of geochemical processes in mantle rocks and ultrabasic complexes}

Batanova, V G, Sobolev, A V, Schmincke, $\mathrm{H}-\mathrm{U}$

Graham, C M, Kinny, P D, Harte, B, Valley, J M

Lowry, D, Mattey, D P, Macpherson, C G, Harris, J W

Rampone, E, Piccardo, G B, Vannucci, R, Bottazzi, P, Zanetti, A

Shimizu, N

Takazawa, E, Shimizu, N, Frey, F A

Tribuzio, R, Vannucci, R, Bottazzi, P, Ottolini, L

Vannucci, R, Bottazzi, P, Ottolini, L, Dal Negro, A, Piccirillo, E M

Witt-Eickschen, G, Kaminsky, W, Harte, B, Seck, H A

Zanetti, A, Vannucci, R, Bottazzi, P, Oberti, R, Ottolini, L
Mantle lherzolites from Troodos ophiolites: mineralogy and ion probe geochemistry of clinopyroxenes

The nature and scale of stable isotope disequilibrium in the mantle: Ion and laser microprobe evidence

Evidence for stable isotope and chemical disequilibrium associated with diamond formation in the mantle

Melt impregnation in ophiolitic peridotites: an ion microprobe study of clinopyroxene and plagioclase

Chemical zoning of garnets in peridotites and diamonds

Development and evolution of the lithospheric mantle: a case study from the Horoman peridotite, Japan

Residence of REE in low-temperature eclogites from Ligurian Alps, north western Italy: the role of accessory minerals

The trace element variations in clinopyroxenes from spinel peridotite xenoliths from western Victoria (Australia)

Trace element concentrations in amphibole and/or clinopyroxene from composite mantle xenoliths of the West Eifel (Germany): an ion-microprobe study

Crystal-chemical variations in amphiboles close to a hornblendite vein: implications for models of mantle metasomatism

\section{4h. Mafic-ultramafic rocks and complexes}

Becker, $\mathrm{H}$

Cocherie, A, Rossi, $\mathrm{P}$

Essawy, M A, El-Metwally, A A

Frick, L R, Lambert, D D, Reeves, S J, Heaman, L M

Jordaan, L J, Scheepers, R, Barton, E S

Lahtinen, $\mathbf{R}$
Geochemistry of high-temperature garnet peridotite complexes from Lower Austria (Southern Bohemian Massif): Crustal signatures in the lower lithosphere

Characterization and evolution of mafic magmatism in the late orogenic Variscan batholith of Corsica

Pan African mafic-ultramafic cumulate intrusions SW Sinai Massif: mineralogy, geochemistry and crustal growth

Platinum group element and osmium isotope evidence for the origin of Scourie dykes

The correlation between the isotope distribution and geochemistry of mafic to intermediate igneous rocks from the South African West Coast

Preliminary notes on the geochemical characteristics of mantle during 1.93-1.79 $\mathrm{Ga}$ beneath the Svecofennian domain, Finland 
Lahtinen, $\mathrm{R}$, Lestinen, $\mathrm{P}$, Korkiakoski, E, Salminen,, R, Sanstrom, H, Savolainen, $H$, Vallius, $\mathrm{H}$

Leelanandam, C

Lu, M, Hofmann, A W, Rivalenti, R, Mazzucchelli, M McDonald, I, de Wit, M J, Bizzi, L A

Meisel, T, Biino, G G, Nagler, T Nagler, T F, Frei, R

Pudlo, D, Franz, G

Ramo, O T, Boyd, W W, Vaasjoki, M, Cameron, R L, Ryckman, D A

Schaaf, P, Heinrich, W

Van Baalen, $\mathrm{M} \mathbf{R}$

Wai, K M, Abbot, M J, Grady, A E
Rock geochemistry research project (RGRP) in the Geological Survey of Finland

The Kondapalli layered complex, Andhra Pradesh, India: Geology, mineralogy and chemistry

Geochemistry of the lower crustal mafic-ultramafic complex at Finero, Ivrea Zone, N Italy

The geochemistry of the platinum-group elements in kimberlites and the nature of the PGE in the subcratonic lithospheric mantle

Os and $\mathrm{Sm} / \mathrm{Nd}$ isotopic constraints on ultramafic petrogenesis in the Helvetic basement

A combined $\mathrm{U}-\mathrm{Pb}$-zircon, $\mathrm{Pb}-\mathrm{Pb}-\mathrm{Nd}$ isotope investigation on the Masirah ophiolite, Oman: Indications for generation of acidic rocks by pure differentiation of a depleted mantle source

Magma generation in a deep seated magma chamber - evidence by mineral-, geochemical, and isotope data from Pan-African dyke rocks (Bir Safsaf/SW Egypt)

1.3 Ga mafic magmatism of the St Francois mountains area of SE Missouri

Geochemical, Sr-Nd isotopic, and P-T data on a Central Mexican xenolith suite: Evidence for upper mantle and lower crust compositions

Metapyroxenites from New Idria, California, USA

The Sadowa igneous complex, Eastern Papua New Guinea: Ophiolite or not?

\section{Geochronometry and thermal history}

Ayres, M, Vance, D

Bartlett, J M, Harris, N B W, Hawkesworth, C J, Santosh, M

Biino, G G, Oberli, F, Meier, M

Boggs, $\mathrm{K} \mathrm{J} \mathrm{E}$, van Breemen, $\mathrm{O}$, Corriveau, L, Sawyer, E W

Cosca, M A, Essene, E J, Mezger, K, Pluijm, B van der

Costa, S, Rey, P, Todt, W, Goldstein, S L

Dahl, P S

Erel, Y, Harlavan, Y, Stein, M, Ron, $\mathrm{H}$, Blum, J

Gallagher, K

George, M T, Reddy, S M
Constraints on the thermal evolution of the Indian Himalaya from manganese and erbium distributions in metapelitic garnets

Tectonic and thermal evolution of South India during the PanAfrican orogeny

Rates of metamorphic processes constrained by petrology and single zircon U-Pb chronology: a case study on former $\mathrm{HP}$ HT mafic rocks from central Alps

New insights on metamorphism in the central metasedimentary belt of Quebec, Grenville Province

Protracted extensional unroofing and deep crustal rotation in the Grenville Orogen, Ontario

Evolution of the lower continental crust during post-thickening collapse

'Ionic porosity' as a predictor of diffusion parameters in thermochronometric minerals: evidence and tectonic implications

U-Pb dating of magnetite from the Kinsman Quartz Monzonite, New Hampshire, USA: Implications for dating natural remnant magnetization

An evolutionary approach to thermal history modelling with fission track data

Differential unroofing and inherited radiogenic strontium in the Western Himalaya 
Hensen, B J, Zhou, B

Kelley, S P, Arnaud, N O, Okay, A I

Kinny, $\mathrm{P}$, Friend, C

Mezger, $\mathrm{K}$

Ostermann, M, Scharer, U, Buhl, D, Deutsch, A

Ramsbotham, W, Inger, $S$, Cliff, R A, Rex, D, Barnicoat, A C

Thoni, M

Vance, D, Kelley, S

Vavra, G, Gebaurer, D, Schmid, $\mathbf{R}$

Wijbrans, J R, Helmers, $\mathrm{H}$, Sopaheluwakan, J

Zhu, X K, O'Nions, R K, Belshaw, N S
Two cycles of granulite facies metamorphism detected by $\mathrm{Sm}$ $\mathrm{Nd}$ dating of garnet: implications for the $\mathrm{Sm}-\mathrm{Nd}$ closure temperature

Anomalously old Ar-Ar ages in high pressure metamorphic terrains

A new insight into Lewisian chronology

Geochronology and metamorphism

$\mathrm{U}-\mathrm{Pb}$-data for baddeleyite and zircon from the Foy offset sike (Sudbury, Canada)

Time constraints on the metamorphic and structural evolution of the southern Sesia-Lanzo zone, Western Italian Alps

Chronological constraints for Variscan vs Alpine eclogite facies metamorphism in the basement units of the Eastern Alps

Ar-Ar constraints on erosional versus extensional unroofing in orogenic belts: the Zankas Himalaya, NW India

The thermal history of the lower crust recorded by zircon growth and recrystallization: an ion microprobe (SHRIMP) study from the Ivrea zone

The age and thermal evolution of blueschists from south-east Sulawesi, Indonesia: The case of slowly cooled phengites

Dating of granulite facies metamorphism and depletion: SIMS chronometry of micro-scale monazite inclusion in garnet 


\section{Effects of water content, temperature and pressure on actinide tracer diffusion in melts of haplogranitic composition}

\author{
J.E. Mungall \\ D.B. Dingwell
}

Bayerisches Geoinstitut, Universität Bayreuth, D-95440

Bayreuth, Germany.

\section{Introduction}

An understanding of the rates and mechanisms of $\mathrm{U}$ and $\mathrm{Th}$ diffusion in silicate melts and glasses is necessary to fully understand such diverse phenomena as U-Th decay series disequilibria, melt-crystal partitioning, and leaching of actinides from nuclear waste glasses. Uranium diffusivities have been determined in anhydrous borosilicate nuclear waste glasses (Dunn, 1987), and numerous investigators have studied release rates of actinides during leaching of glass by hydrothermal solutions (e.g. Schreiber et al., 1985). Dissolved water is known to enhance diffusion of other high field strength elements in silicate melts (e.g. Harrison and Watson, 1983). In light of the abundance of water in felsic silicate melts, and the prevalence of water-rich compositions in ancient weathered natural glasses (Mungall and Martin 1994), we have investigated the effects of water content and temperature on $U$ and $T h$ diffusion rates in a synthetic haplogranite composition at pressures ranging from one atmosphere to 10 kbars.

\section{Experiments}

Two batches of bubble-free, homogeneous glass (one clean HPG-8 (see Holz et al., 1992 for composition), the other doped with $0.1 \%$ each of $\mathrm{U}$ and $\mathrm{Th}$ ) were prepared by fusing oxide and carbonate powders in a $\mathrm{Pt}$ crucible at $1600^{\circ} \mathrm{C}$, stirring for several days with a $\mathrm{Pt}$ spindle, and cooling in air. For one-atmosphere anhydrous experiments, the glass was drilled and sliced into 8 mm-diameter discs $2 \mathrm{~mm}$ thick with polished ends. Diffusion couples were made by juxtaposing the two glasses in a $\mathrm{Pt}$ capsule. For high pressure experiments the clean glass was ground and tamped into Pt cylinders; in water-bearing runs double distilled water was added to give $4.5 \mathrm{wt}$. \% water, after which doped glass powder was poured in, tamped, and the cylinder was welded shut. One atmosphere experiments were conducted in a box furnace; high pressure experiments were conducted in a $1 / 2^{\prime \prime}$ piston-cylinder apparatus with alumina pressure medium. One atmosphere experiments were quenched by removing from the furnace, whereas high pressure experiments were quenched by turning off the furnace. Run products were sectioned and polished for analysis on a Cameca WDS microprobe at $25 \mathrm{kV}$ accelerating voltage and $100 \mathrm{nA}$ probe current, with a defocussed beam. Most traverses were 1 to $3 \mathrm{~mm}$ wide; if the flat extremes of the diffusion profile were not at least $500 \mu \mathrm{m}$ wide the experiment was discarded. Because there is no variation in the matrix through the couple, data were collected and processed as raw X-ray counts at 1 to 7 (usually 5) micron point spacings.

\section{Results}

Profiles were fit to an error function to minimize chi $^{2}$; all the products used had infinite couple geometry and to show no compositional dependence, i.e., the estimated diffusion coefficients are assumed to approximate tracer diffusion coefficients. Uncertainty was estimated by finding the range of values of $\mathrm{D}$ within which $\mathrm{chi}^{2}$ gave $95 \%$ confidence of an insignificant residual. The variation of $D_{U}$ and $D_{T h}$ with temperature, water content and pressure is shown in Fig. 1 for all experiments. The logarithms of both $U$ and $T h$ diffusivities are linear against reciprocal temperature, and are given by the following Arrhenius relationships:

$$
\begin{array}{r}
\mathrm{D}_{\mathrm{U}}=7.94 \times 10^{-3} \exp \left\{260 \mathrm{~kJ} \mathrm{~mol}^{-1} / \mathrm{RT}\right\} \text { dry, } 1 \mathrm{bar} \\
\mathrm{D}_{\mathrm{Th}}=1.92 \times 10^{-1} \exp \left\{318 \mathrm{~kJ} \mathrm{~mol}^{-1} / \mathrm{RT}\right\} \text { dry, } 1 \mathrm{bar} \\
\mathrm{D}_{\mathrm{U}}=\mathrm{D}_{\mathrm{Th}}=9.25 \times 10^{-1} \exp \{239 \mathrm{~kJ} \mathrm{~mol}-1 / \mathrm{RT}\} \\
4.5 \% \mathrm{H}_{2} \mathrm{O}, 10 \mathrm{kbar} \text { (Eyring) }
\end{array}
$$

These lines are shown in Fig. 1; also shown are the diffusivities predicted by the Eyring equation $D$ $=\mathrm{kT} / \zeta \lambda$ (using viscosity $\zeta$ from Shaw (1972) at 10 kbar, measured viscosities from Dingwell et al. (1992) at 1 bar; jump distance $\lambda=2.3 \AA$; $k=$ Boltzmann's constant). The relation we have chosen for $D_{U}$ and $D_{T h}$ in hydrous melts at 10 kbar is that predicted by the Eyring equation, because regressed lines do not differ significantly 


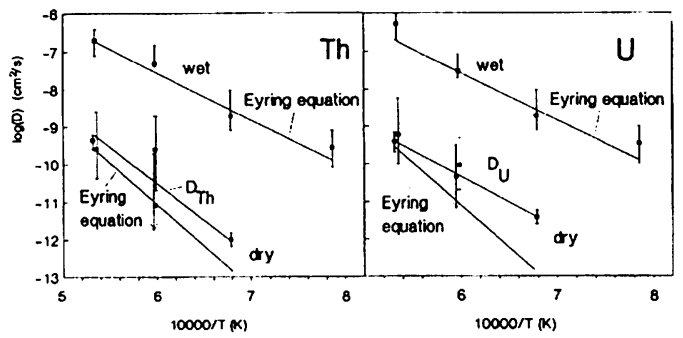

FIG. 1.

from it. This correspondence probably indicates that $\mathrm{U}$ and $\mathrm{Th}$ diffusion are controlled by the same thermally activated processes that control viscosity. $\mathrm{Th}$ is moderately well predicted by the Eyring equation in the anhydrous melts. However, the difference in activation energy of $D_{U}$ from that of $\mathrm{D}_{\mathrm{Th}}$ and viscous flow at 1 bar may indicate decoupling of $\mathrm{D}_{\mathrm{U}}$ from melt viscosity (transition to intrinsic diffusivity). This observation suggests that $\mathrm{U}$ diffusivities at the low temperatures relevant to nuclear waste leaching could be very much higher than equations 2) and 4) suggest. The inference of decoupling hinges on only one measurement at $1200^{\circ} \mathrm{C}$; further work will test this possibility with experiments at lower temperatures.

Oxygen fugacity was invoked by Dunn (1987) as a major control on the diffusivity of $U$ in borosilicate glass. In our experiments, oxygen fugacity ranged from 0.21 in the 1 bar experiments to lower values presumed to lie near NNO in the $10 \mathrm{kbar}$ experiments (unbuffered). Over this range in oxgen fugacities $U$ is expected to change from a hexavalent state (uranyl ion $\mathrm{UO}_{2}^{2+}$ ) at high $f_{\mathrm{O}_{2}}$ to a mix of pentavalent and quadrivalent ions at lower $f_{\mathrm{O}_{2}}$; this change may be responsible for the apparent transition from extrinsic to intrinsic diffusion between $10 \mathrm{kbar}$ and 1 bar, since uranyl ion has a much lower charge density than do $\mathrm{U}^{4+}$ and $\mathrm{U}^{5+}$. An alternative explanation is that at low water contents (high viscosity) we are observing the intrinsic diffusivity of $U$ whereas at high water contents (low viscosity) the increased mobility of network formers overtakes the intrinsic diffusivity, resulting in Eyring behaviour. An interesting consequence of this hypothesis is that as a magma cools and degasses the diffusivities of $U$ and $T h$ may progress from being subequal to showing differences of several orders of magnitude.

The data show that isotopic decoupling of $U$ and $\mathrm{Th}$ decay series by differences in diffusivity are not expected in hydrous silicic melts over a very wide range of temperatures, pressures and water contents, but that at magmatic temperatures in water-poor magmas transport of $U$ may be significantly faster than that of $\mathrm{Th}$, resulting in a potential for $\mathrm{U}-\mathrm{Th}$ fractionation.

In a reconaissance experiment at $1400^{\circ} \mathrm{C}, 10$ kbar, dry, the estimated diffusivities of both $U$ and Th are not significantly different from those calculated at the same temperature for the 1 bar experiment. The apparent slight offset to higher values may result from the diminished melt viscosity at higher pressure, but confirmation of this suggestion would require further work.

\section{Conclusion}

Diffusion of $U$ and $T h$ in haplogranitic melt is Arrhenian over the temperature range 1000 to $1600^{\circ} \mathrm{C}$, with diffusivities in water-rich melts predicted by the Eyring equation. At high oxygen fugacities and low water contents the diffusion of Th may remain coupled to melt viscosity, but $\mathrm{U}$ diffusion appears to be intrinsic, with diffusivity one to two orders of magnitude faster than the predicted Eyring diffusivity at $1200^{\circ} \mathrm{C}$. $\mathrm{U}$ and $\mathrm{Th}$ may therefore become fractionated by transport processes under these conditions. Clarification of the effects of pressure and $f_{\mathrm{O}_{2}}$ over a wider range of temperatures is presently under way.

\section{References}

Dingwell, D.B., Knoche, R., Webb, S.L. and Pichavant, M. (1992) Amer. Mineral., 77, 457-61.

Dunn, T. (1987) J. Non-Cryst. Solids, 92, 1-10.

Harrison, T.M. and Watson, E.B. (1983) Contrib. Mineral. Petrol., 84, 66-72.

Holz, F., Behrens, H., Dingwell, D.B. and Taylor, R.P. (1992) Chem. Geol., 96, 289-302.

Mungall, J.E. and Martin, R.F. (1994) Geochim. Cosmochim. Acta, 58, 75-83.

Schreiber, H.D., Balazs, G.B. and Solberg, T.N. (1985) Phys. Chem. Glass., 26, 35-45.

Shaw, H.R. (1972) Amer. J. Sci., 272, 870-93. 